Provided for non-commercial research and education use. Not for reproduction, distribution or commercial use.

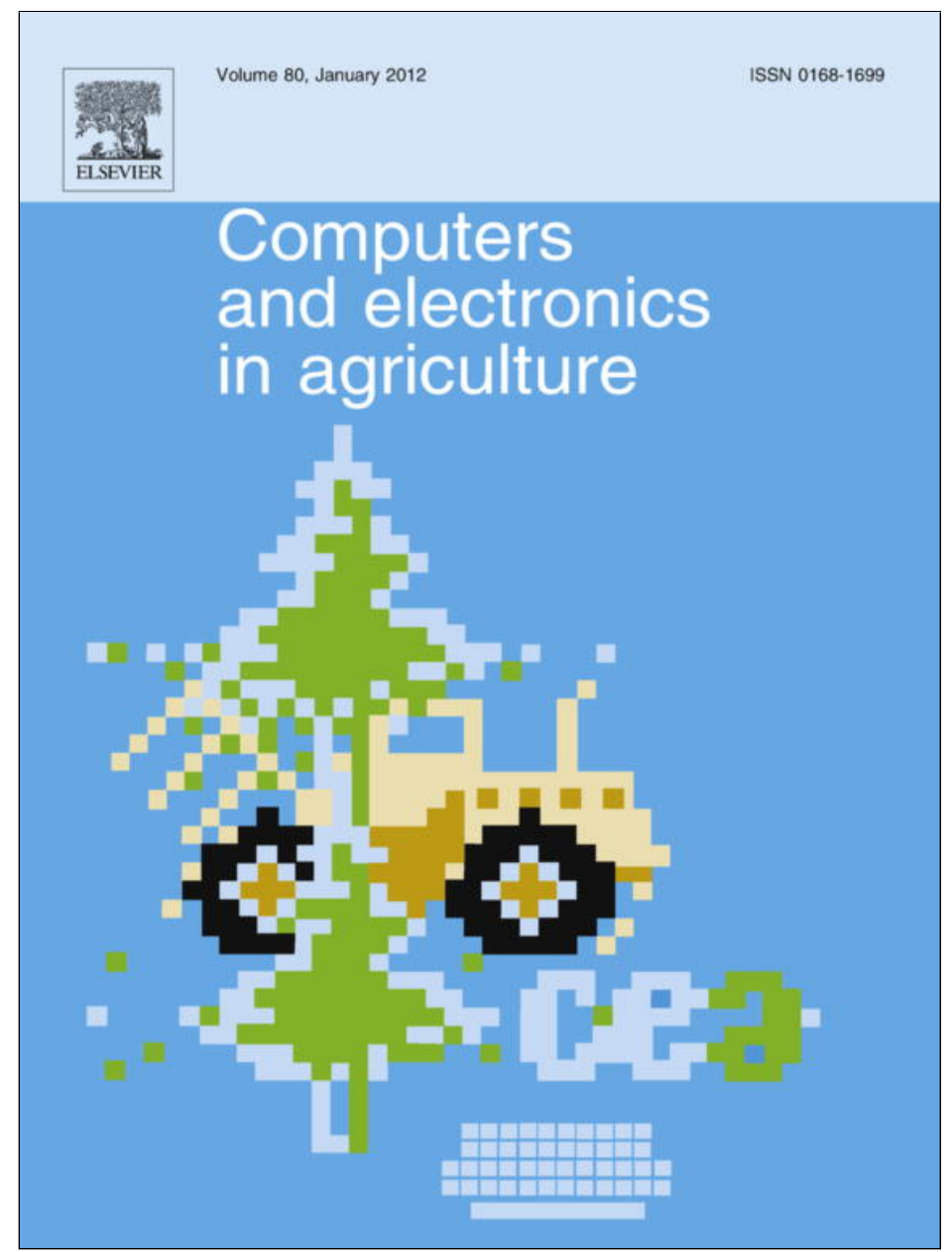

This article appeared in a journal published by Elsevier. The attached copy is furnished to the author for internal non-commercial research and education use, including for instruction at the authors institution and sharing with colleagues.

Other uses, including reproduction and distribution, or selling or licensing copies, or posting to personal, institutional or third party websites are prohibited.

In most cases authors are permitted to post their version of the article (e.g. in Word or Tex form) to their personal website or institutional repository. Authors requiring further information regarding Elsevier's archiving and manuscript policies are encouraged to visit:

http://www.elsevier.com/authorsrights 


\title{
Application of the fuzzy Failure Mode and Effect Analysis methodology to edible bird nest processing
}

\author{
Chian Haur Jong ${ }^{\mathrm{a}}$, Kai Meng Tay ${ }^{\mathrm{a}, *}$, Chee Peng Lim ${ }^{\mathrm{b}}$ \\ ${ }^{a}$ Faculty of Engineering, Universiti Malaysia Sarawak, 94300 Kota Samarahan, Sarawak, Malaysia \\ ${ }^{\mathrm{b}}$ Centre for Intelligent Systems Research, Deakin University, Geelong Waurn Ponds Campus, Locked Bag 20000, Geelong, VIC 3220, Australia
}

\section{A R T I C L E I N F O}

\section{Article history:}

Received 5 November 2012

Received in revised form 27 February 2013

Accepted 25 April 2013

\section{Keywords:}

Failure Mode and Effect Analysis

Fuzzy Inference System

Edible bird nest

\begin{abstract}
A B S T R A C T
The focus of this paper is on the production processes of Edible Bird Nest (EBN) in Sarawak, Malaysia. Sarawak and Sabah (two states of Malaysia in the Borneo Island) are known as the second ranked resource area (after Indonesia) of the world for EBN production. In spite of the popularity of EBN as a food source and the important economic status of the EBN industry, the use of a quality and risk assessment tool for the production of EBN is new. As such, the implementation of an advanced quality and risk assessment tool, i.e., the fuzzy Failure Mode and Effect Analysis (FMEA) methodology, for EBN processing is described in this paper. Data and information are gathered from several EBN production sites, and fuzzy FMEA is adopted to analyze the collected data/information. It is worth mentioning that the EBN production in Sarawak is relatively traditional. As such, this work makes an important contribution to modernization of the EBN production industry in Sarawak, i.e., to improve the production process and ensure the quality of EBN via the use of a formal quality and risk assessment tool. Besides, this paper contributes to a new application of fuzzy FMEA to the agriculture and food domain.
\end{abstract}

(C) 2013 Elsevier B.V. All rights reserved.

\section{Introduction}

Edible Bird Nest (EBN) (or known as "the Caviar of the East") is the nest of swiftlets which is edible and consumed by humans as (healthy) food (Hobbs, 2004; Marcone, 2005). EBN is made up of saliva produced by cave-nesting swiftlets of two genera, i.e., glossy swiftlets (genus Collocalia Gray 1840) and echolocating swiftlets (genus Aerodramus Oberholser 1906) (Lim and Earl of Cranbrook, 2002). The white-nest swiftlets (Aerodramus fuciphagus) and the black-nest swiftlets (Aerodramus maximus) are heavily exploited for commercial purposes (Lim and Earl of Cranbrook, 2002). Traditionally, raw EBN originates from the natural limestone caves (Jordan, 2009). However, with a high demand of EBN from China, the traditional caves are insufficient to produce enough EBN to support the increasing need of the market (Jordan, 2009). Thus, in Malaysia, swiftlets farming has appeared as an alternative industry to supplement raw EBN. This helps preserve swiftlets species and avoid the over exploitation of the raw EBN resources (Lim and Earl of Cranbrook, 2002). Today, swiftlets farming and EBN processing have emerged as a popular urban industry among Southeast Asia countries, including Malaysia (Lim and Earl of Cranbrook, 2002; Jordan, 2009).

\footnotetext{
* Corresponding author. Tel.: +60 6016 4400098; fax: +60 6082583410.

E-mail address: kmtay@feng.unimas.my (K.M. Tay).
}

It is generally believed by the Chinese community that EBN has a high medical value. Hobbs (2004) listed a number of claimed benefits of consuming EBN soup, which includes dissolving phlegm, relieving gastric troubles, aiding renal functions, raising libido, enhancing complexion, alleviating asthma, suppressing cough, curing tuberculosis, strengthening the immune system, speeding recovery illness and surgery, increasing energy and metabolism, and improving concentration. Recent researches have also shown that extracts from EBN have a significant effect for inhibiting the infection of influenza (Guo et al., 2006; Yagi et al., 2008), and avoiding bone loss (Matsukwa et al., 2011).

Despite the popularity of EBN as a food source, it is challenging to ensure the quality of EBN. From the literature, many activities on ensuring and enhancing the quality of EBN have been reported. Lin et al. (2009) developed a method based on an analysis of cytochrome $b$ gene in mitochondrial deoxyribonucleic acid (DNA) for genetic identification of EBN. Given a sample of EBN, the proposed method was able to help identify the species of birds that produced the sample; hence distinguishing between authentic and counterfeit EBN. A combination of observational and analytical investigative technique to determine the authenticity of EBN from bioprocessed food was proposed by Marcone (2011). A combination of DNA polymerase chain reaction (PCR) and protein-based two dimensional gel electrophoresis-based method for rapid and reliable identification of genuine EBN products was reported by Wu et al. (2010). In short, the investigations in Lin et al. (2009), 
Marcone (2011) and Wu et al. (2010) focused on developing reliable methods to determine the authenticity of EBN.

In addition to establishing the authenticity of EBN, to the best of our knowledge, there are relatively few reports on the implementation of a quality and risk assessment tool for the food industry, not to mention EBN production. In this paper, the EBN production processes (i.e., farming, harvesting, processing, and packaging) are explained as a series of systematic manufacturing or engineering operations. It is important to implement a quality and risk assessment tool for EBN production in order to (i) identify problems and solutions systematically, (ii) improve quality, reliability, and safety, (iii) collect data/information for reducing future failures as well as capturing engineering knowledge, (iv) reduce production time and cost, (v) improve production yield. In this paper, the focus is on the use of an advanced quality and risk assessment tool, i.e., the fuzzy Failure Mode and Effect Analysis (FMEA), for improving the EBN production processes.

FMEA is a popular and practical quality and risk assessment tool. It is useful to define, identify, and eliminate known and/or potential failures, problems, errors from a system, design, process, and/or service (Stamatis 2003). A failure mode is defined as the manner in which a component, subsystem, system, or process can potentially fail to meet the designed intent (Liu et al., 2010). A successful FMEA implementation helps the manufacturing team to identify potential failure modes based on their past experience with similar products or processes; hence enabling the team to eliminate or reduce system failures with the minimum effort and resource expenditure. From the literature, the use of FMEA in the food industry is not new. Scipioni et al. $(2002,2005)$ demonstrated an FMEA which was integrated with the hazard analysis and critical control points approach in a food company. It was used as a tool to assure product quality and as a means to improve the operational performance of the production cycle. Besides, FMEA was employed as a risk assessment tool in salmon manufacturing (Arvanitoyannis and Varzakas, 2008) and red pepper spice production processes (Ozilgen et al., in press). However, the use of FMEA in EBN production processes is new.
Recently, a number of enhancements to FMEA using soft computing modeling techniques have been proposed, e.g., the use of a Fuzzy Inference System (FIS) to replace the conventional Risk Priority Number (RPN) model in FMEA (Liu et al., 2010; Yang et al., 2008; Guimares and Lapa, 2004; Tay and Lim, 2006). The conventional RPN score is obtained by multiplying three risk factors, i.e., Severity $(S)$, Occurrence $(O)$, and Detect $(D), R P N=S \times O \times D)$. As an alternative, the FIS-based RPN model uses an FIS model to aggregate these three risk factors, and produces a fuzzy RPN (FRPN) score, i.e., $F R P N=f_{R P N}(S, O, D)$. The FIS-based RPN model has been successfully applied to a variety of domains, e.g. maritime (Yang et al., 2008), nuclear power plant (Guimares and Lapa, 2004), and semiconductor manufacturing (Tay and Lim, 2006). The FIS-based model has several advantages. These include (i) the FIS-based model allows the modeling of nonlinear relationships between the RPN score and the three risk factors (Bowles and Peláez, 1995); (ii) it is robust against uncertainty and vagueness (Yang et al., 2008); and (iii) the scales of the attribute(s) can be qualitative, instead of quantitative (Bowles and Peláez, 1995).

To the best of our knowledge, the use of fuzzy FMEA in EBN production has never been reported before. Besides, it is worth mentioning that the use of fuzzy logic related techniques in agriculture is a new and popular research direction. Examples include a fuzzy decision support system for nitrogen fertilization (Papadopoulos et al., 2011), a fuzzy controller for decreasing tomato cracking in greenhouses (Hahn, 2011), as well as a fuzzy logicbased disease diagnosis system for crops (Kolhe et al., 2011). The aim of this paper is to analyze EBN production processes with the fuzzy FMEA methodology and to improve EBN food processing control and management. Potential failure modes and their $S, O$, and $D$ ratings are firstly determined. The FIS-based RPN model is constructed with data/information gathered from domain experts. It is essentially a computerized risk assessment and failure analysis tool that mimics human reasoning. The tool is implemented as a computer software, which can be used to compute analyze fuzzy RPN scores of failure modes, and subsequently prioritize the failure modes for appropriate remedial actions. This study is important

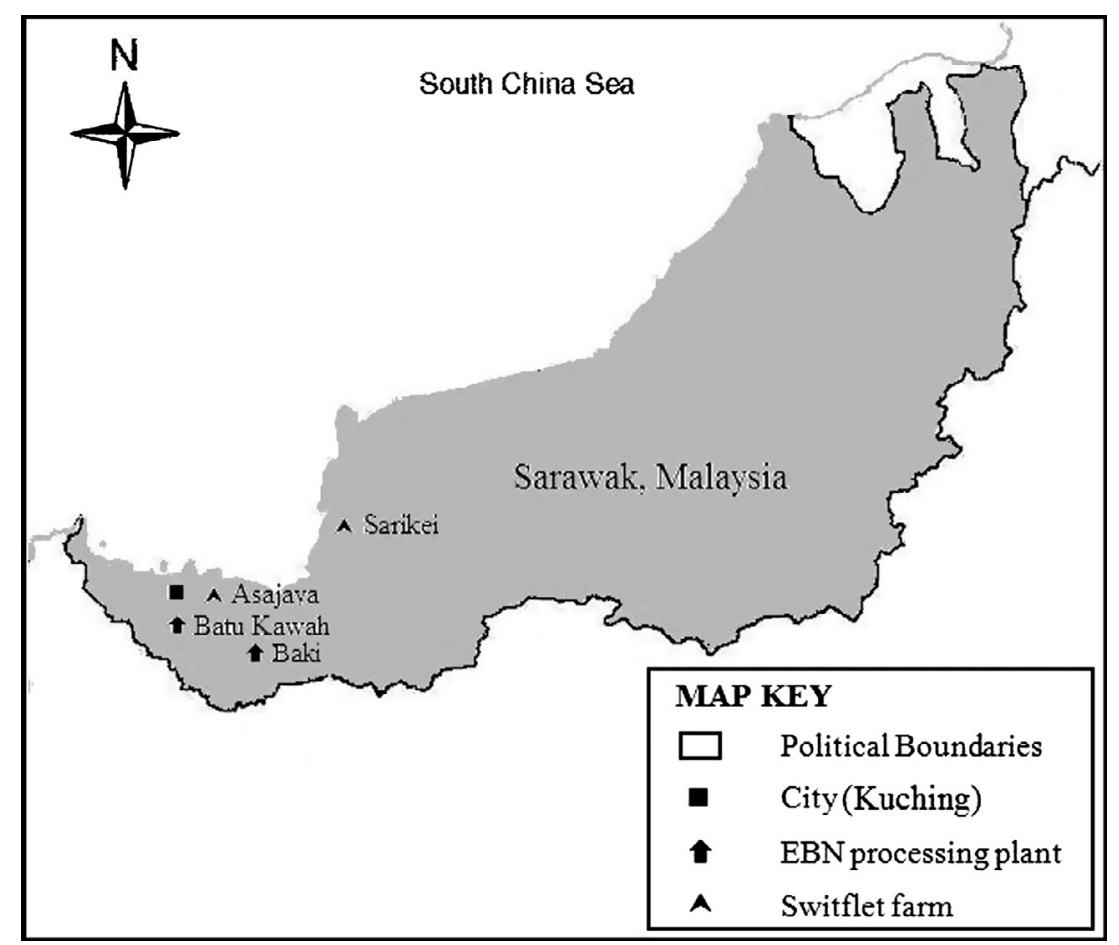

Fig. 1. Geographical locations of two swiftlets farms and two EBN production plants in Sarawak, Malaysia. 


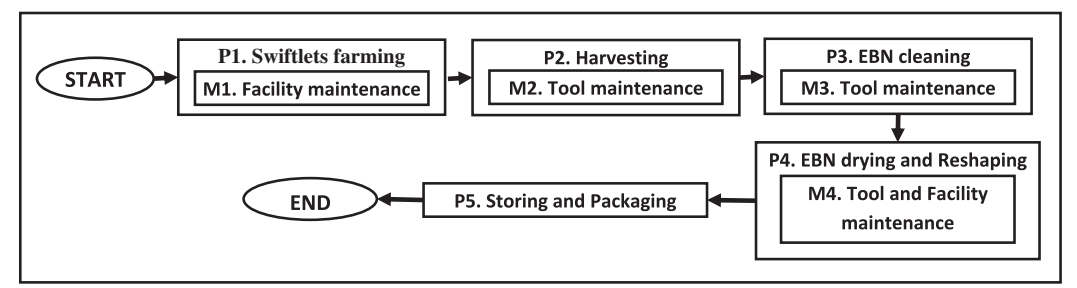

Fig. 2. The EBN production process.

because it contributes towards improving the quality and safety issues of EBN related products. Besides, this study establishes an effective management for swiftlets cultivation and EBN food processing. Real data/information gathered from two swiftlets farms located at Sarikei and Asajaya and two EBN processing plants located at Batu Kawah and Baki (all in Sarawak) are used in this study.

This paper is organized as follows. In Section 2, the geographical locations of the EBN farms and production plants used in this study are described. Besides, the EBN production procedure is explained. In Section 3, the use of the fuzzy FMEA methodology in EBN production is detailed. In Section 4, the evaluation results with fuzzy FMEA are presented. Finally, concluding remarks and suggestions for further work are given in Section 5 .

\section{Background}

In this section, the geographical locations of the swiftlets farms and EBN productions plants are firstly described. The EBN production processes are then explained in details.

\subsection{Geographical locations}

Fig. 1 depicts the geographical locations of the swiftlets farms and EBN production plants engaged in this study. The two swiftlets farms are located in Sarikei $\left(2^{\circ} 7^{\prime} 4.13^{\prime \prime} \mathrm{N}\right.$ and $\left.111^{\circ} 31^{\prime} 16.36^{\prime \prime} \mathrm{E}\right)$ and Asajaya $\left(1^{\circ} 32^{\prime} 28^{\prime \prime} \mathrm{N}\right.$ and $\left.110^{\circ} 30^{\prime} 52^{\prime \prime} \mathrm{E}\right)$, while the two EBN production plants are located in Batu Kawah $\left(1^{\circ} 31^{\prime} 10^{\prime \prime} \mathrm{N}\right.$ and

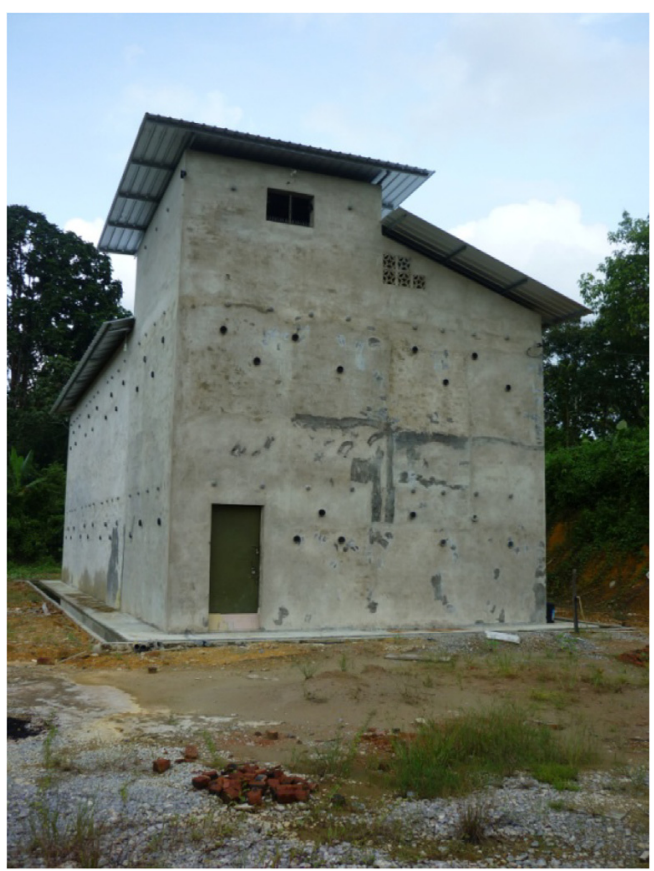

Fig. 3. A swiftlets farm in Sarikei.

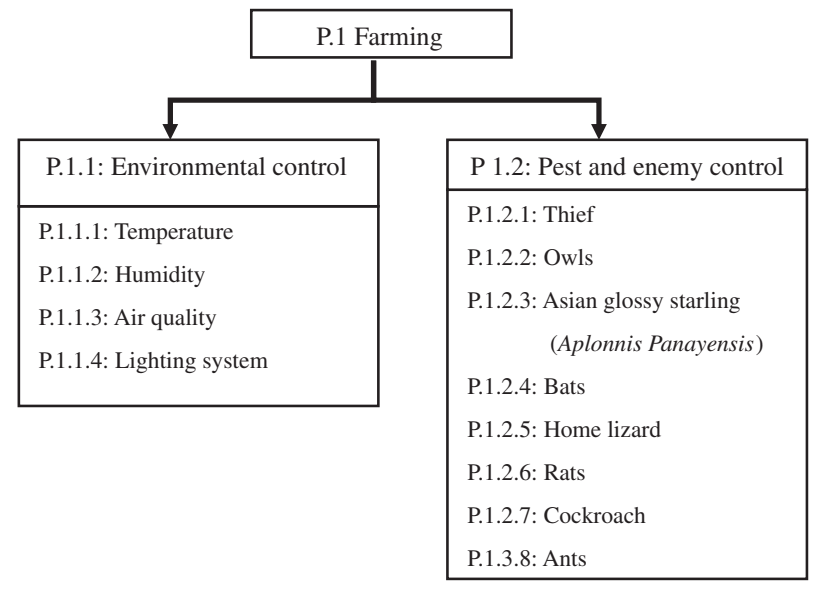

Fig. 4. The management functional block diagram of a swiftlets farm.

$\left.110^{\circ} 19^{\prime} 37^{\prime \prime} \mathrm{E}\right)$ and Baki $\left(1^{\circ} 13^{\prime} 40^{\prime \prime} \mathrm{N}\right.$ and $\left.110^{\circ} 30^{\prime} 24^{\prime \prime} \mathrm{E}\right)$. Real data/ information are gathered from these sites for further evaluation.

\subsection{EBN production}

In general, the EBN production cycle can be divided into five sub-processes, i.e., (i) swiftlets farming (P.1), (ii) harvesting (P.2), (iii) EBN cleaning (P.3), (iv) EBN drying and reshaping (P.4), and (v) storing and packaging (P.5), as depicted in Fig. 2. These sub-processes are explained in Sections 2.2.1-2.2.5, respectively. A number of tools and/or facilities used for maintenance in the first four subprocesses are labeled as M.1, M.2, M.3 and M.4, respectively.

\subsubsection{Swiftlets farm and farming process}

A swiftlets farm (also known as "swiftlets house", "swiftlets nesting house", "swiftlets farm house" or "swiftlets farming house") is a man-made building with a designated environment (e.g., music and temperature control) that attempts to attract and accommodate the swiftlets. An example of a swiftlets farm in Sarikei is shown in Fig. 3. In swiftlets farming, the swiftlets do not need to be fed, as they pray for their food. Thus, the swiftlets farm is not a closed cage, as it only provides accommodation for the swiftlets to inhabit while they yield raw EBN.

The farming process involves two important aspects of control, i.e., (i) environmental control (P.1.1) and (ii) pest and enemy control (P.1.2), as depicted in Fig. 4. On one hand, the first aspect of control suggests that it is important to maintain a good farming environment as a habitat for the swiftlets, as this attracts the swiftlets to migrate in. Besides, it ensures the quality of the EBN produced. A few important criteria are the control of temperature, humidity, air quality, and light intensity.

On the other hand, the second aspect of control suggests that a swiftlets farm is usually subjected to many threats, which include theft (by humans), pests and/or natural enemies. EBN is expensive; thus a proper security system to avoid theft is necessary. Besides, 


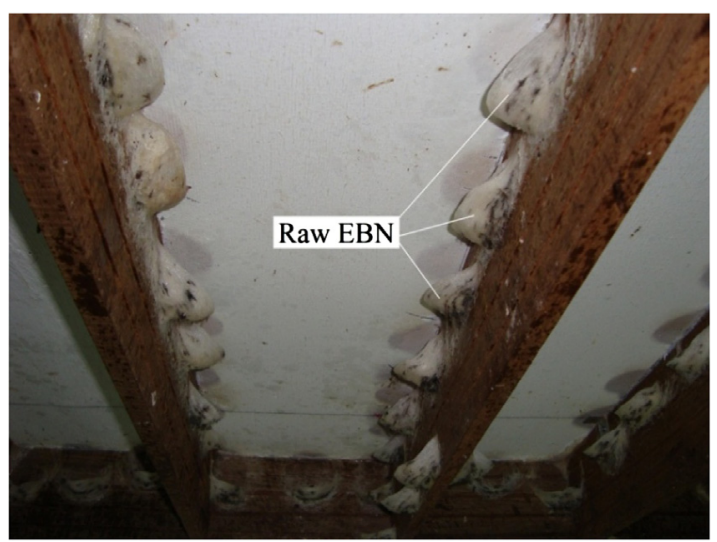

Fig. 5. Raw EBNs in a swiftlets farm.

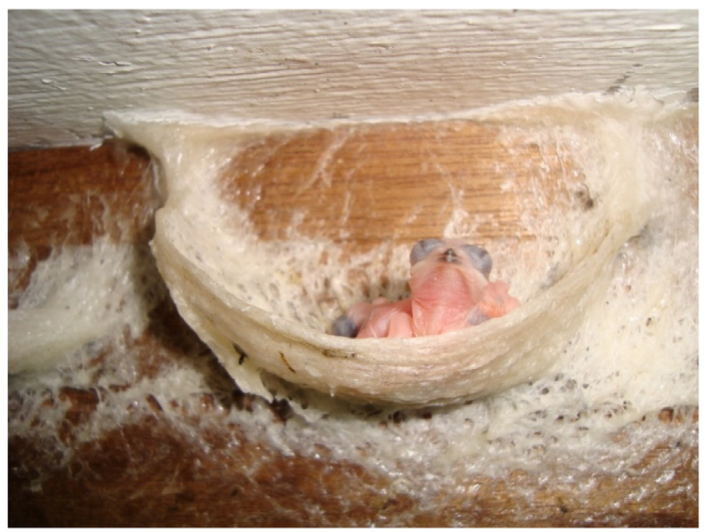

Fig. 6. A raw EBN accommodated by baby swiftlets.

pest control is another important aspect in the design and operation of a swiftlets farm. Among the popular pests and nature enemies are owls and bats, which are predators of the swiftlets. Asian glossy starling (Aplonis panayensis), home lizard, ants, rats, and cockroach can cause destruction of the bird's nest. They are also the predators for baby swiftlets. Besides that, Asian glossy starling competes with the swiftlets for the habitat.

A swiftlets farm is usually equipped with several facilities, i.e., an alarm security system, a spot light, power supply, a sound system, and a humidifier. An alarm security system is installed to ensure the security of the swiftlets farm and to avoid the invasion of thieves. A spot light is installed at the entrance of the swiftlets

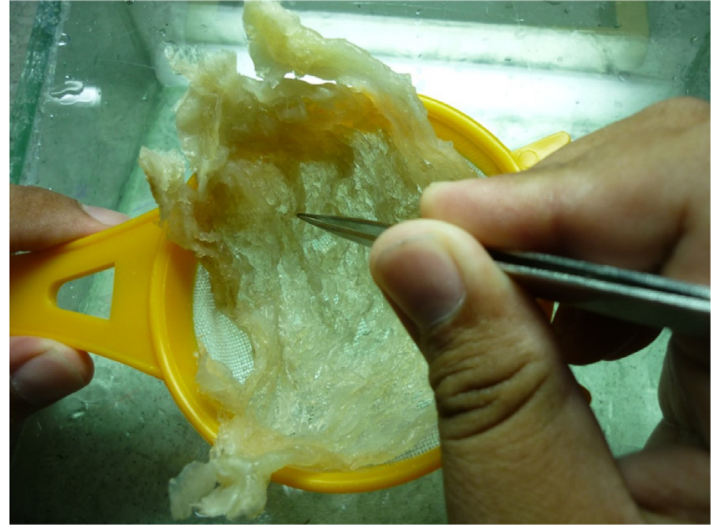

Fig. 8. Cleaning of a raw EBN with a pincer.

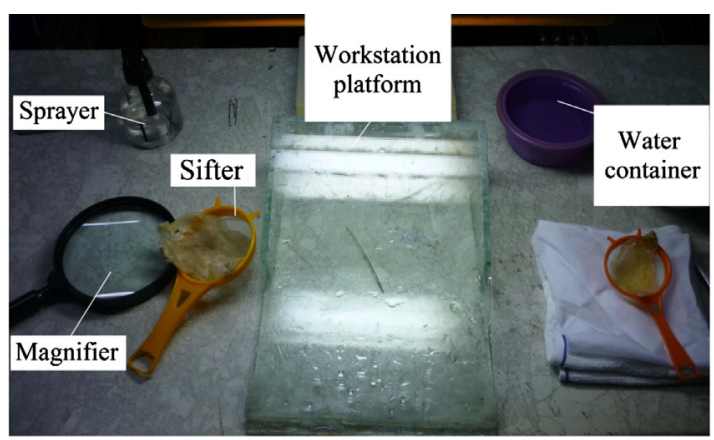

Fig. 9. The tools used in the EBN cleaning process.

farm. It is pointed outward and is used to avoid the invasion of owls and bats at night. The power supply provides electricity for the farm. A sound system is designed to attract the swiftlets. A humidifier is used to control the humidity of the farm.

\subsubsection{Harvesting}

Harvesting is a process of shoveling the raw EBN (as shown in Fig. 5) from the crossbeam of a swiftlets farm. To ensure the safety of the swiftlets, only empty nests abandoned by the swiftlets after breeding are shoveled. Inspection of a raw EBN with a swiftlets corner mirror is necessary to ensure that there are no eggs or baby swiftlets before harvesting. Fig. 6 depicts baby swiftlets in a raw EBN.

The taping knife and swiftlets corner mirror are important tools for harvesting. A sharp taping knife eases the harvesting process.

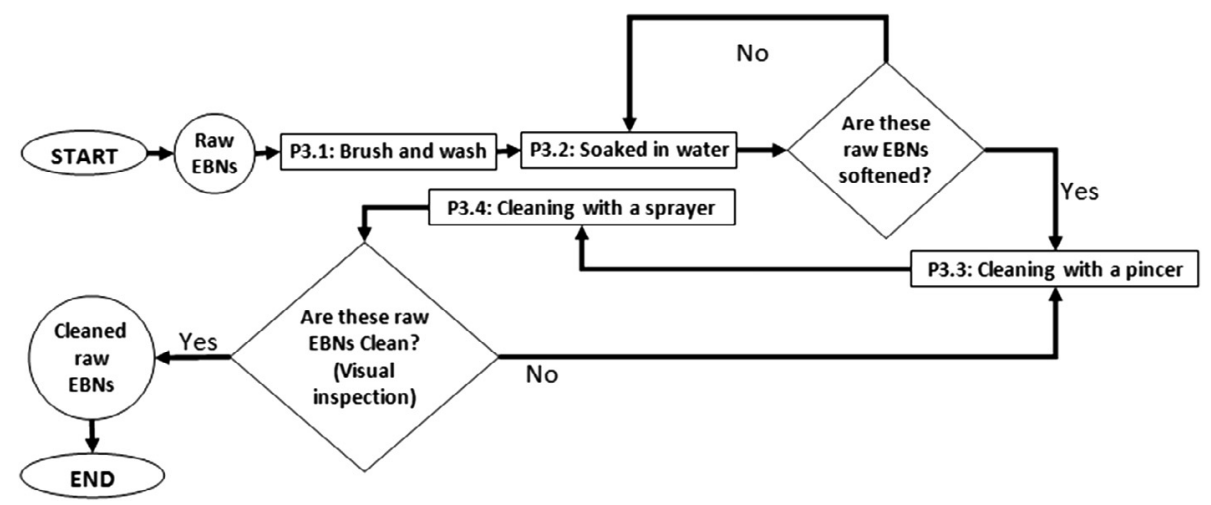

Fig. 7. A flow chart for the EBN cleaning process. 


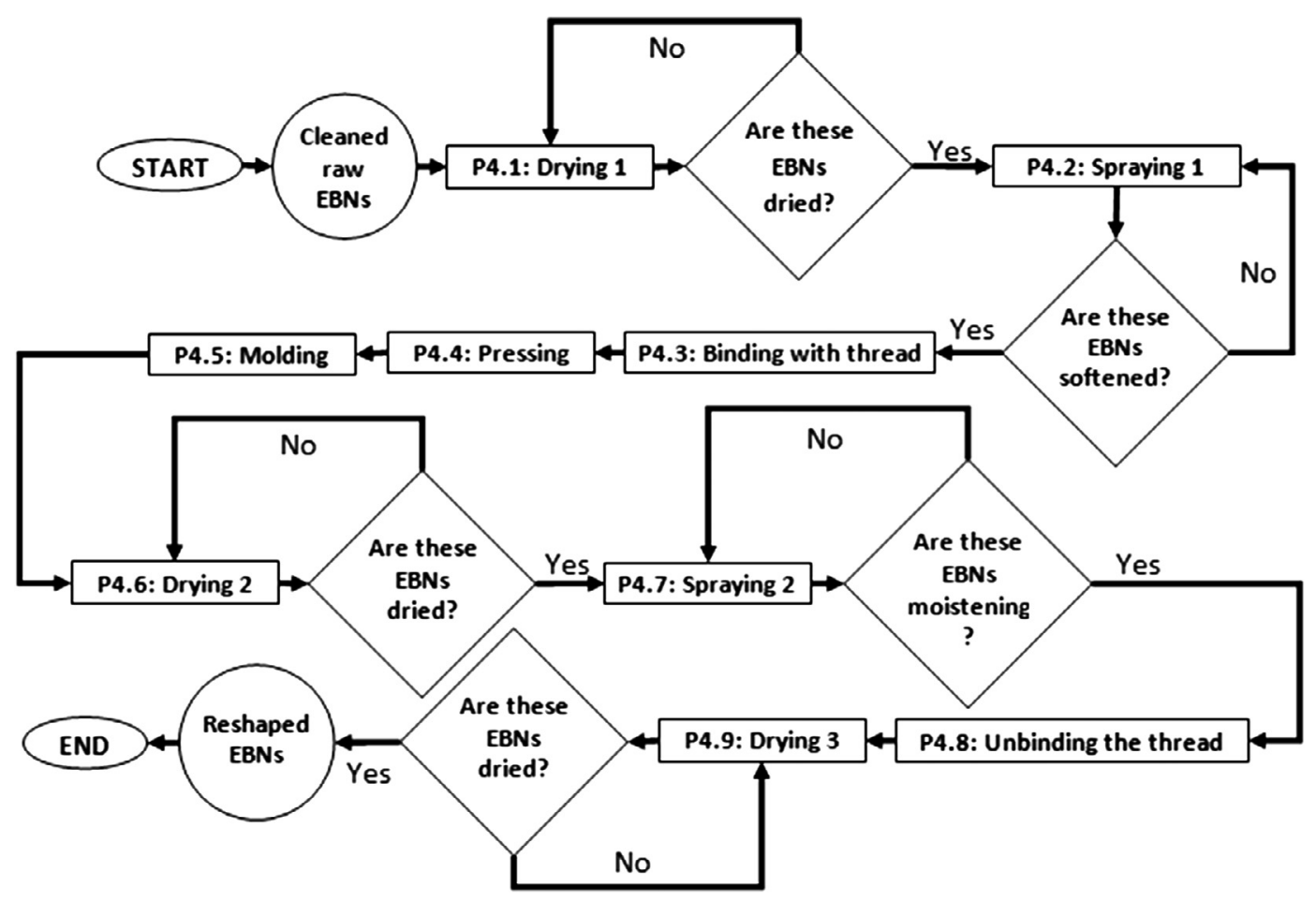

Fig. 10. A flow chart for the drying and reshaping process.

The swiftlets corner mirror can be broken easily during the harvesting process.

\subsubsection{EBN cleaning}

A harvested raw EBN has to be cleaned before being consumed. A flow chart for the EBN cleaning process is depicted in Fig. 7. Firstly, the raw EBN is washed with brushes (i.e., P3.1). It is then softened by soaking into water (i.e., P3.2). The softened raw EBN is then cleaned with a pincer (i.e., P3.3, as shown in Fig. 8). A sprayer is used to speed up the cleaning process (i.e., P3.4). During the cleaning process, P3.3 and P3.4 are repeated until the raw EBN is clean. Visual inspection is deployed in these operations.

Fig. 9 depicts some commonly used tools, i.e., pincer, sprayer, sifter, workstation platform, magnifier, and water container, during the EBN cleaning process. The pincer and sprayer are used to clean the raw EBN. A workstation platform is used to support the EBN cleaning process. The sifter is used to hold the wet raw EBN in order to avoid them from tearing apart. The magnifier is used for visual inspection. Water (in a container) is used to clean these tools.

Tool maintenance in this process is important in order to avoid contamination in EBN products. Hence, the used tools have to be cleaned frequently. Besides, the pincer has to be sharpened frequently with a grindstone, as a blunt pincer can slow down the EBN cleaning process.

\subsubsection{EBN drying and reshaping}

EBN drying and reshaping is a complicated and tedious process. The process is highly manual, as summarized in Fig. 10. The cleaned raw EBN (which is wet and soft) is dried and re-shaped. It needs to be dried (i.e., P4.1 Drying 1 ) to make the reshaping process possible. During P4.1, the cleaned raw EBN in a gelatinous-like state is dried. To ease the reshaping process, the EBN is sprayed with very little amount of water (i.e., P4.2 Spraying 1 ). The purpose of P4.2 is to soften the dried EBN and to ensure that it is able to be reshaped (i.e., soften and bendable). A softened EBN is then

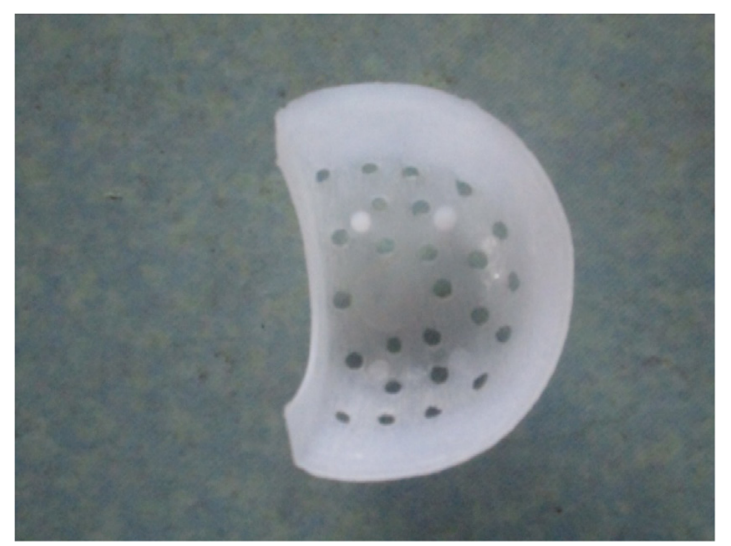

Fig. 11. The mold used for the molding process.

bounded with a thread (i.e., P4.3). The thread is used to fix the EBN into a specific shape. The bounded EBN is pressed (i.e., P4.4) to reduce the gap within. Then, the EBN is put into a mold (i.e., P4.5). Fig. 11 illustrates the mold that is used in the molding process.

The EBN needs to be dried again (i.e., P4.6 Drying 2). P4.6 attempts to dry the EBN and ensure that it is not deformed when it is taken out from the mold. The dried EBN from P4.6 is fragile. Therefore, it is important to spray (P4.7 Spraying 2) a little amount of water to moisten the EBN surface and slightly soften the dried EBN. P4.7 reduces the risk of cracking of the dried EBN during the next step (i.e., P4.8 unbinding the thread). The EBN is then dried again (i.e., P4.9 Drying 3).

A customized oven is an important equipment to dry the EBN. The oven consists of a casing, fans, bulbs, and nets, as shown in Fig. 12. The casing traps the heat in the oven. The fan is used to allow internal air circulation, and ensure an equilibrium of heat distribution in the oven. The bulbs generate heat, and the nets are 


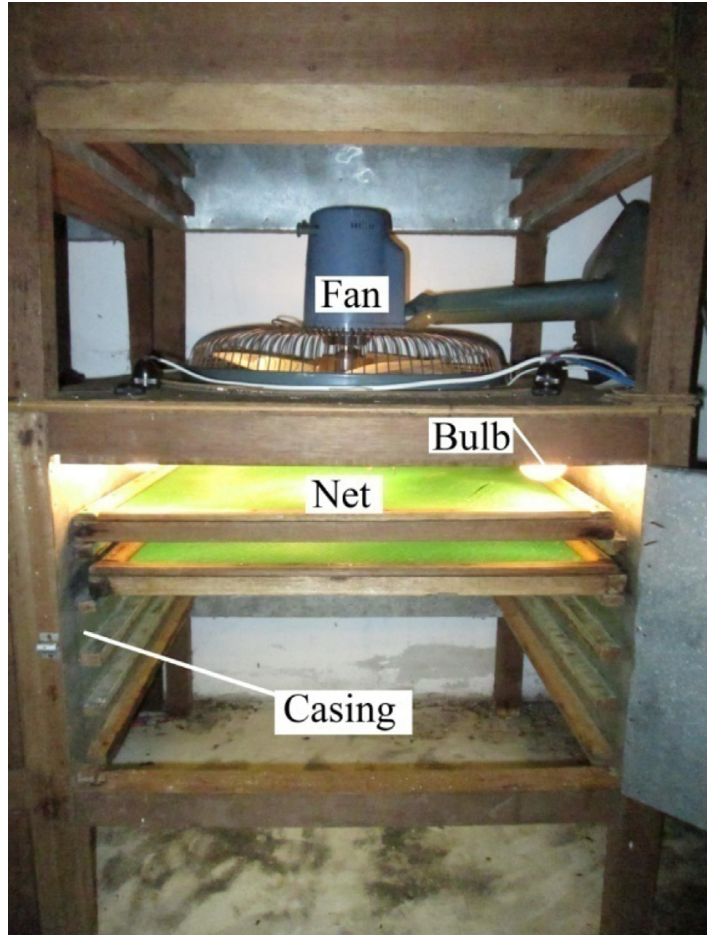

Fig. 12. The oven which is used for drying the EBNs.

used to hold the molds. It is important to ensure the cleanliness of the oven in order to avoid contamination of the EBN during the drying processes.

The EBN drying and reshaping process involves both facility and tool maintenance. The facility maintenance involves constant monitoring of the oven's cleanness and the functionality of its important parts (i.e., casing, fans, bulbs, and nets). The tool maintenance mainly focuses on ensuring the cleanness of the mold.

\subsubsection{Storing and packaging}

The processed (reshaped) EBN is dry and crumbly. It is temporary stored in containers in the room temperature. The processed EBN is packaged according to orders. The EBN product is weighted according to the amount requested by the customers. The product is priced according to the weight. Dry and crumbly EBN is easily cracked during the delivery process. Thus, bubble wrap or sponge is used.

\section{The fuzzy FMEA methodology}

In this section, the use of fuzzy FMEA with an FIS-based RPN model is described. In Section 3.1, the FIS-based RPN model is firstly explained. The fuzzy FMEA procedure is explained in Section 3.2, with a flow chart included. In Sections 3.3 and 3.4, the procedures for fuzzy membership function design and fuzzy rules gathering are explained.

To ensure the validity and effectiveness of the RPN scores, it is important to maintain the monotonicity and output resolution properties (Tay and Lim, 2008a,b, 2011a). For the FIS-based RPN model to always satisfy the monotonicity property (Tay and Lim, 2008a,b, 2011a), it is essential to ensure that $d F R P N / d x \geqslant 0$, where $x \in[S, O, D]$. Two mathematical conditions (i.e., the sufficient conditions) which presented in Tay and Lim (2008a,b, 2011a), Kouikoglou and Phillis (2009), and Won et al. (2002) are adopted as the governing equations for fuzzy membership function design and fuzzy rules gathering. The sufficient conditions indicate that a zero-order Sugeno FIS model is able to satisfy the monotonicity property if (1) the fuzzy membership functions are designed according to an inequality (as detailed in Section 3.3); (2) the fuzzy rules are monotonic (as detailed in Section 3.4). For the FIS-based RPN model to always satisfy the output resolution property (Tay and $\operatorname{Lim} 2008$ a,b, 2011a), i.e., $d F R P N / d x>0$ must be true. Hence, a rule refinement procedure (as detailed in Section 3.5) is included to improve the output resolution property of the FIS-based RPN model.

In general, an FIS modeling process can be generalized to five steps (Lin and Lee, 1996), as follows: (1) define the input and output variables, (2) determine the fuzzy partition of the input and output spaces and choose the fuzzy membership functions, (3) determine the fuzzy rules, (4) design the inference mechanism, (5) choose a defuzzification operator. To keep this paper short and concise, we embed these steps as part of the fuzzy FMEA procedure.

\subsection{An FIS-based RPN model}

In this paper, the FIS-based RPN model is adopted as a quality and risk assessment tool for EBN production. Tables 1-3 are the scale tables for $S, O$, and $D$, respectively. Each scale table is divided into three columns, i.e., Ranking, Linguistic Term, and Description. Column "Ranking" states the score intervals. These intervals are assigned with a linguistic term, as in column "Linguistic Term $\left(A_{x}^{j_{x}}\right)$ ", where $x \in[S, O, D]$. There are $m_{x}$ intervals for each $S, O$, and $D$, respectively. A detailed description of each interval is summarized in column "Description". Each interval score is represented by a fuzzy membership function (i.e., $\mu_{x}^{j_{x}}(x)$ ), with a linguistic term of $A_{x}^{j_{x}}$. In this paper, the lower and upper limits of $S, O$, and $D$, are 1 and 10 , respectively.

As an example, a score from 1 to 2 is assigned with the linguistic term of "Very Low" for $S$, i.e., $A_{S}^{1}$. The interval is used to explain a failure with an unobvious effect, which can be ignored. Besides, even if the failure occurs, the yield and the product quality are still excellent. In this study, this interval is represented by a fuzzy membership function of $\mu_{S}^{1}(S)$. The same explanation applies to $O$ and $D$.

The relationship between the RPN score and $S, O$, and $D$ is represented by a set of fuzzy rules, as follows.

$$
\text { If } \left.\left(\boldsymbol{S} \text { is } A_{S}^{j_{S}}\right) \text { and }\left(\boldsymbol{O} \text { is } A_{O}^{j_{O}}\right) \text { and }\left(\boldsymbol{D} \text { is } A_{D}^{j_{D}}\right) \text {, then ( RPN is } B^{j_{s} j_{0}, j_{D}}\right)
$$

In this study, a zero-order Sugeno FIS model is adopted. Note that $\mu_{S}^{j_{S}}(S) \times \mu_{O}^{j_{0}}(O) \times \mu_{D}^{j_{D}}(D)$ is the compatibility grade, or the firing strength, for each fuzzy rule, while $b^{j_{S} j_{0} j_{D}}$ is the fuzzy singleton for $B^{j_{s} j_{O}, j_{D}}$. Here, it is assumed that $b^{j_{S}, j_{0}, j_{D}}$ is the point where $B^{j_{s}, j_{O}, j_{D}}$ equals to 1 . The FRPN score is obtained via a weighted average between the firing strength and the fuzzy singleton, as in following equation:

$$
\begin{aligned}
F R P N & =f(S, O, D) \\
& =\frac{\sum_{j_{D}=1}^{j_{D}=m_{D}} \sum_{j_{0}=1}^{j_{0}=m_{0}} \sum_{j_{S}=1}^{j_{S}=m_{S}}\left(\mu_{S}^{j_{S}}(S) \times \mu_{O}^{j_{O}}(O) \times \mu_{D}^{j_{D}}(D) \times b^{j_{S} j_{0} j_{D}}\right)}{\sum_{j_{D}=1}^{j_{D}=m_{D}} \sum_{j_{0}=1}^{j_{0}=m_{0}} \sum_{j_{S}=1}^{j_{S}=m_{S}}\left(\mu_{S}^{j_{S}}(S) \times \mu_{O}^{j_{0}}(O) \times \mu_{D}^{j_{D}}(D)\right)}
\end{aligned}
$$

Note that a zero-order Sugeno FIS model is a special case of the Mamdani FIS model. The Mandami FIS model consists of a fuzzifier, a fuzzy rule base, an aggregator, and a defuzzifier. In the zero-order Sugeno FIS model, each fuzzy rule consequent is specified by a fuzzy singleton, i.e., a pre-defuzzified consequent (Jang et al., 1997). 
Table 1

Scale table for Severity.

\begin{tabular}{|c|c|c|}
\hline Ranking & $\begin{array}{l}\text { Linguistic term } \\
\left(A_{S}^{j_{s}}\right)\end{array}$ & Description \\
\hline $1-2$ & Very low & $\begin{array}{l}\text { - Effect of the potential failure mode is not obvious and can be ignored } \\
\text { - Excellent yield and product quality }\end{array}$ \\
\hline $3-4$ & Low & $\begin{array}{l}\text { - Very minor impact to the production yield } \\
\text { - Failures cause a minor impact to EBN food production process control. The consequence will cause a minor effect to the products' } \\
\text { cosmetic appearance and packaging }\end{array}$ \\
\hline $5-7$ & Medium & $\begin{array}{l}\text { - Failures lead to the issue of minor security breaches of the farm, habitat of the swiftlets is affected by some of the pests and enemies of } \\
\text { the swiftlets. The consequence will cause a reduction in the population of the swiftlets and the yield of the farm } \\
\text { - Failures cause a minor impact to the production yield }\end{array}$ \\
\hline $8-9$ & High & $\begin{array}{l}\text { - Failures lead to the issue of serious security breaches of the farm. Safety of the swiftlets will be threatened by its enemies, such as } \\
\text { thieves and predators }\end{array}$ \\
\hline 10 & Very High & $\begin{array}{l}\text { - Failures cause a major impact to the production yield } \\
\text { - Failures lead to impacts to product safety and quality } \\
\text { - Compliance to law } \\
\text { - Major impact to the reputation of the company and the products } \\
\text { - Lead to failure to yield management }\end{array}$ \\
\hline
\end{tabular}

Table 2

Scale table for Occurrence.

\begin{tabular}{lll}
\hline Ranking & Linguistic term $\left(A_{O}^{j_{o}}\right)$ & Description \\
\hline 1 & Extremely Low & • Failures happen at least once ever \\
$2-3$ & Very Low & - Failures happen at least once within $6-12$ months \\
$4-5$ & Low & - Failures happen at least once within $1-6$ months \\
$6-7$ & Medium & - Failures happen at least once within 1-30 days \\
$8-9$ & High & - Failures happen at least once within 1-8 working hours \\
10 & Very High & • Failures happen many times within 1 hour \\
\hline
\end{tabular}

Table 3

Scale table for Detect.

\begin{tabular}{|c|c|c|}
\hline Ranking & Linguistic Term $\left(A_{D}^{j_{D}}\right)$ & Description \\
\hline $1-3$ & Very High & $\begin{array}{l}\text { Detection is excellent } \\
\text { - Control actions can almost detect the failure on the spot and appropriate actions are taken to solve the failure and the weakness } \\
\text { - Prevent the excursion from occurring }\end{array}$ \\
\hline $4-6$ & High & $\begin{array}{l}\text { Detection is good } \\
\text { - Control actions can almost detect the failure on the spot within the same process module or steps } \\
\text { - In farm management, control actions can detect the failure within } 1 \text { day } \\
\text { - Appropriate actions are available to solve the failure and the weakness }\end{array}$ \\
\hline $7-8$ & Medium & $\begin{array}{l}\text { Detection is acceptable } \\
\text { - Control actions can detect the failure within one to two process modules or steps } \\
\text { - In farm management, control actions can detect the failure within one to } 3 \text { days } \\
\text { - Appropriate actions are available. However the failure can be tricky and hard to solve }\end{array}$ \\
\hline 9 & Low & $\begin{array}{l}\text { Hard to detect } \\
\text { - Control actions may not detect the failure } \\
\text { - Appropriate actions may not be available and the failure cannot be solved e }\end{array}$ \\
\hline 10 & Very Low & $\begin{array}{l}\text { Detection is almost impossible } \\
\text { - No control action is available } \\
\text { - No solution is available for solving the failure }\end{array}$ \\
\hline
\end{tabular}

\subsection{The fuzzy FMEA flow chart}

Fig. 13 shows a flow chart of the fuzzy FMEA methodology (Tay and Lim, 2008a,b, 2011a), and the important steps, i.e., steps 2, 3, 4, are further explained in Sections 3.3-3.5, respectively.

\subsection{Fuzzy membership function design}

The fuzzy membership functions for $S, O$, and $D$ are designed according to the respective scale tables (i.e., Tables $1-3$ ). There are a total of 5,6 , and 5 membership functions for $S, O$, and $D$, respectively. The membership functions for $S, O$, and $D$ are depicted in Figs. 14-16, respectively.

The mathematical conditions are adopted as the governing equations for designing the fuzzy membership function. They are used to preserve the monotonicity constraint of the membership functions such that the following inequality is satisfied.

$$
\left(\frac{\mathrm{d} \mu_{x}^{j_{k}+1}(x)}{d x}\right) / \mu_{x}^{j_{k}+1}(x) \geqslant\left(\frac{\mathrm{d} \mu_{x}^{j_{k}}(x)}{d x}\right) / \mu_{x}^{j_{k}}(x)
$$

where $x \in[S, O, D], 1 \leqslant x \leqslant 10$, and $j_{k}=1,2, \ldots, m_{x}-1$

In this study, the Gaussian membership function is selected because of its two important properties (Piegat, 2001), viz., (i) it can lead to smooth, continuously differentiable hypersurfaces of a fuzzy model; (ii) it facilitates theoretical analysis of a fuzzy system because it is continuously and infinitely differentiable, i.e., it has derivatives of any grade. Hence, $\mu_{x}^{j_{x}}\left(x: c_{j_{x}}, \sigma_{j_{x}}\right)=e^{-\left[x-c_{j_{x}}\right]^{2} / 2 \sigma_{j_{x}}^{2}}$, where $c_{j_{x}}$ and $\sigma_{j_{x}}$ parameterize the center and width of the Gaussian 


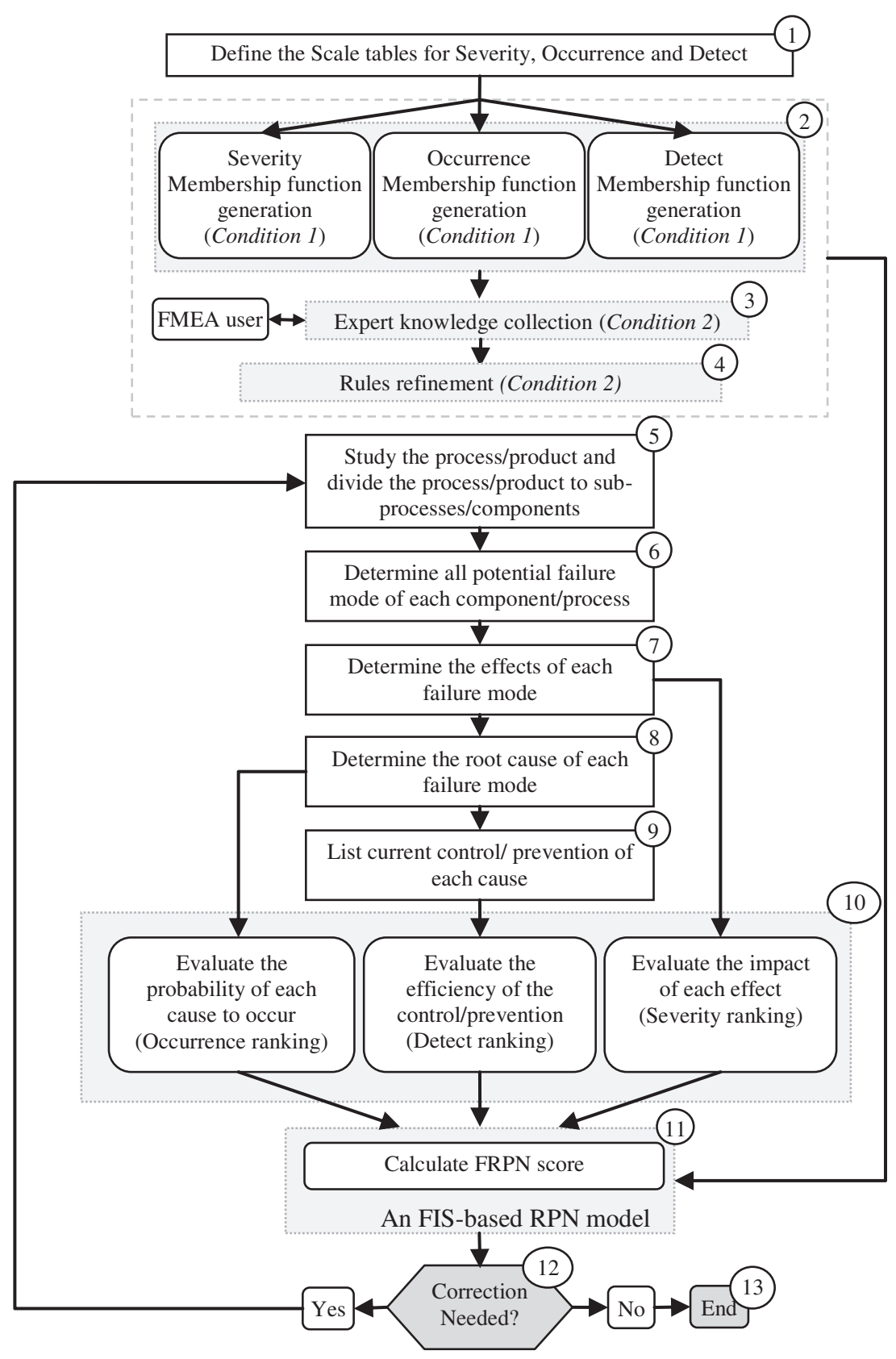

Fig. 13. A fuzzy FMEA methodology.

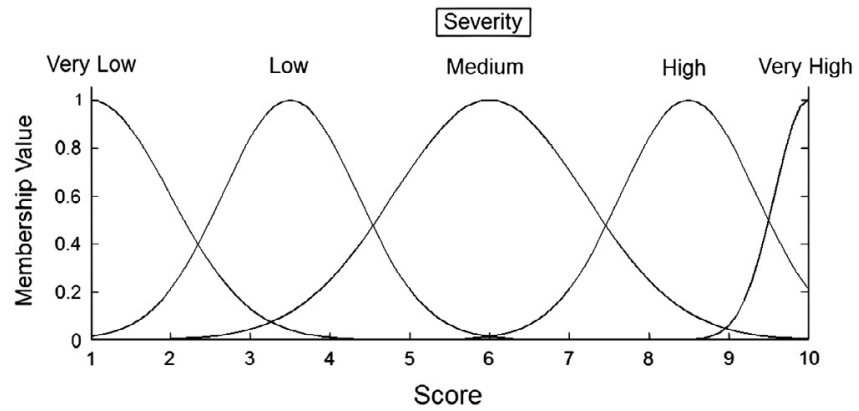

Fig. 14. Membership functions for Severity.

membership function, respectively. The ratio of $\left(\frac{\mathrm{d} \mu_{x}^{j_{x}}(x)}{\mathrm{dx}}\right) / \mu_{x}^{j_{x}}(x)$ is further represented by $E_{x}^{j_{x}}\left(x: c_{j_{x}}, \sigma_{j_{x}}\right)=-\left(1 / \sigma_{j_{x}}^{2}\right) x+\left(c_{j_{x}} / \sigma_{j_{x}}\right)$ (Tay

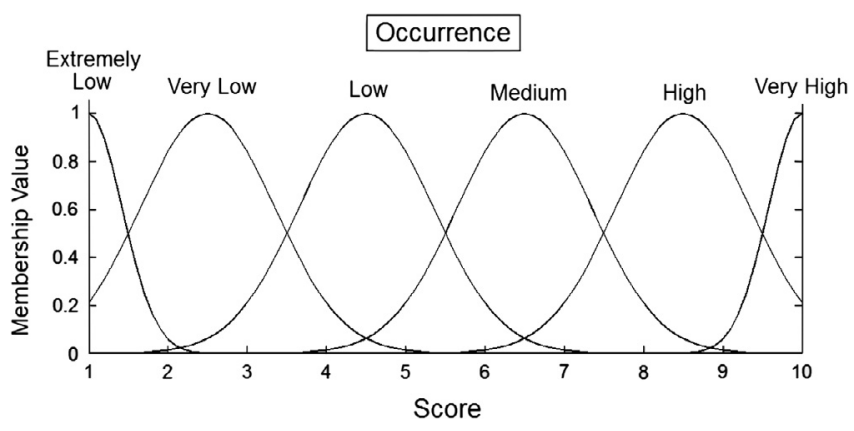

Fig. 15. Membership functions for Occurrence.

and Lim, 2011a). As a result, the fuzzy membership functions can be projected and visualized using the $E_{x}^{j_{x}}\left(x: c_{j_{x}}, \sigma_{j_{x}}\right)$ ratio. Inequality 


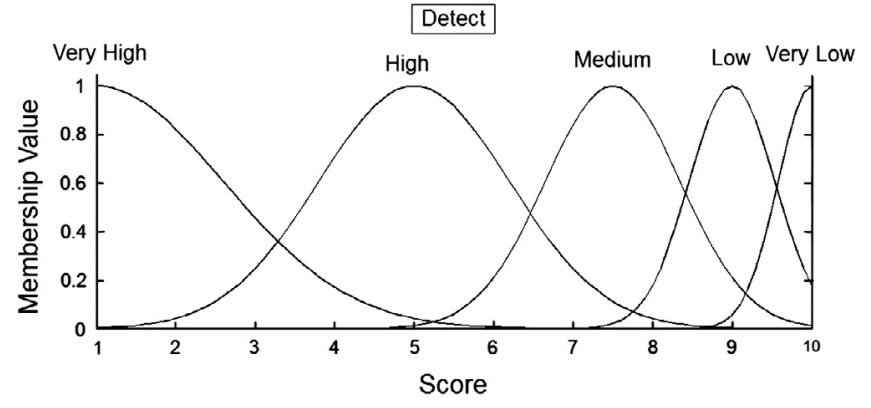

Fig. 16. Membership functions for of Detect.

(2) can be further extended to $E_{x}^{j_{k}+1}(x) \geqslant E_{x}^{j_{k}}(x)$, where $\in[S, O, D], 1 \leqslant x \leqslant 10$, and $j_{k}=1,2, \ldots, m_{x}-1$.

The projections of the fuzzy membership functions for $S, O$, and $D$ are depicted in Figs. 17-19, respectively. From these figures, it can be observed that $E_{x}^{j_{k}+1}(x) \geqslant E_{x}^{j_{k}}(x)$ is satisfied, for $1 \leqslant x \leqslant 10$.

\subsection{Fuzzy rules gathering}

In this study, the FRPN score falls within the range of 1-1000. This range is represented by seven fuzzy membership functions, i.e., $B_{R P N}^{l}, l=1,2, \ldots, 7$, as in Fig. 20, with the linguistic terms of Extremely Low, Very Low, Low, Medium, High, Very High, and Extremely High, respectively. The fuzzy singletons, i.e., $\left.b_{R P N}^{l}, l=1,2, \ldots, 7\right)$, for these fuzzy membership functions are 1 , $287.5,450,600,737.5,855$, and 1000 , respectively.

A total of 150 fuzzy rules $(5 \times 6 \times 5)$ are gathered from domain experts. These fuzzy rules are presented in an If-Then format, as shown in Fig. 21. Consider vector $\bar{s}$, which denotes a subset of $[S, O, D]$, whereby $x$ is excluded from $\bar{s}$, i.e., $\bar{s} \subset[S, O, D] ; x \notin \bar{s}$. The fuzzy rules are gathered in such a way that the fuzzy rule base is monotonic. Mathematically, a fuzzy rule base is monotonic if inequality (3) satisfied.

$b^{j_{k+1} j_{s}} \geq b^{j_{k} j_{s}}, \quad j_{k}=1,2, \ldots, m_{x}-1$

where $x \in[S, O, D]$.An example of two fuzzy rules is shown in Fig. 22. As can be seen, inequality (3) is satisfied, i.e., the consequent of rule \#2 should be equal to or lower than that of rule \#1.

\subsection{Fuzzy rules refinement}

Even though the use of the sufficient conditions as the governing equation for fuzzy membership function design and fuzzy rule gathering can ensure the monotonicity property of the resulting FIS-based RPN model, the model may not satisfy the output resolution property. Thus, fuzzy rules refinement is necessary. Fuzzy rules refinement improves the output resolution property of the

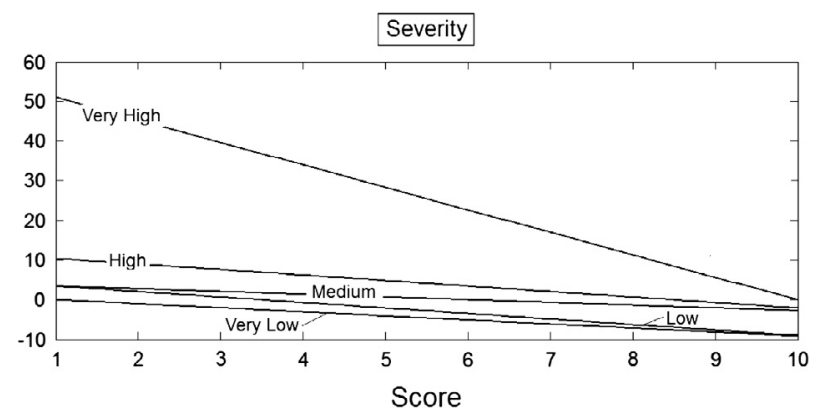

Fig. 17. Projection of the membership functions for Severity.

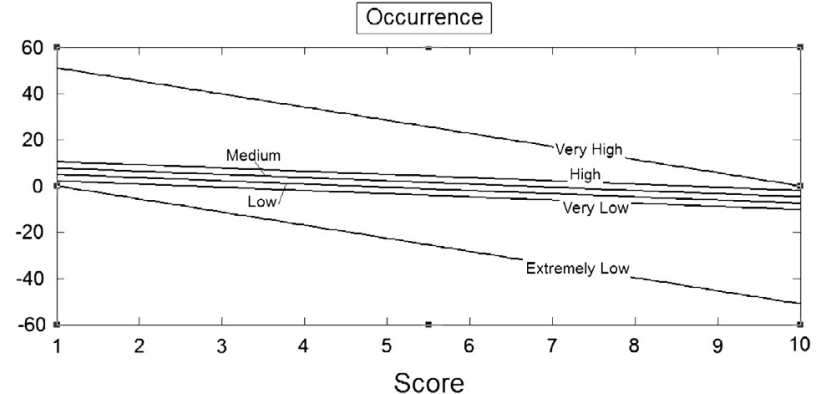

Fig. 18. Projection of the membership functions for Occurrence.

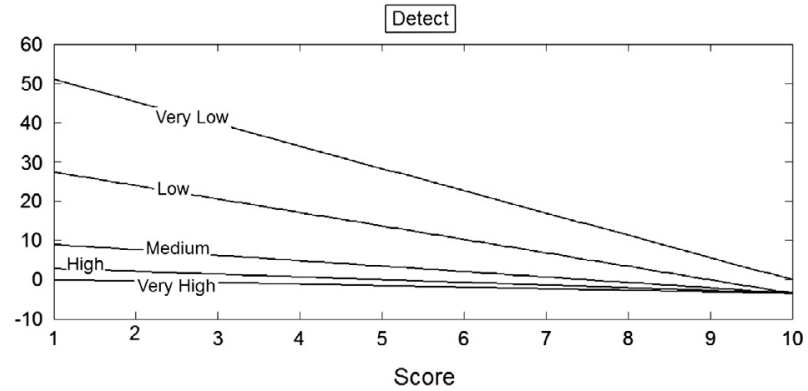

Fig. 19. Projection of the membership functions for Detect.

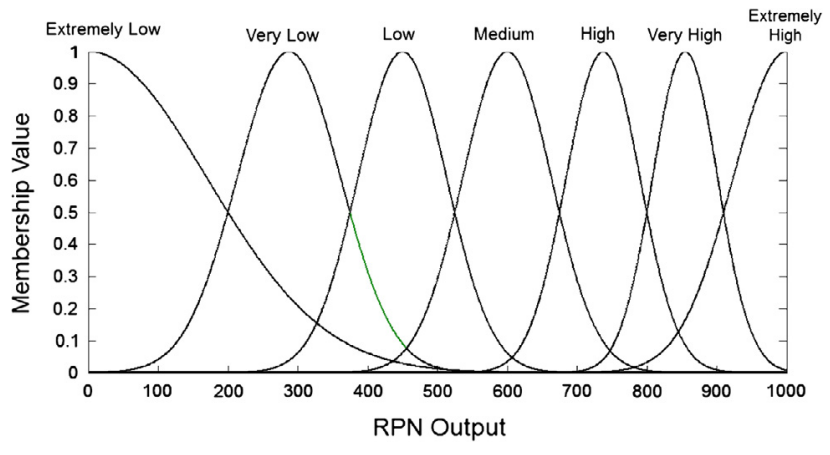

Fig. 20. Fuzzy membership functions for the RPN scores

\section{If $\left(\boldsymbol{S}\right.$ is $\left.A_{S}^{j_{S}}\right)$ AND $\left(\boldsymbol{O}\right.$ is $\left.A_{0}^{j_{0}}\right) A N D\left(D\right.$ is $\left.A_{D}^{j_{D}}\right), T H E N$ (RPN is $\left.B_{R P N}^{l}\right)$}

Fig. 21. A general fuzzy rule for fuzzy FMEA.

Rule 1:
If Occurrence is Very High, Severity is Very High, and Detect is Very Low then
RPN is Extremely High
Rule 2:
If Occurrence is Very High, Severity is Very High, and Detect is Low then the
RPN is Extremely High

Fig. 22. An example of two fuzzy rules.

FIS-based RPN model, without increasing the number of fuzzy membership functions in the FRPN domain. The fuzzy rules are further refined by adding a weight such that inequality (4) is satisfied.

$b^{j_{k+1} j_{s},}>b^{j_{k} j_{s}}, \quad j_{k}=1,2, \ldots, m_{x}-1$

where $x \in[S, O, D]$.A weighted fuzzy rule, as shown in Fig. 23, is used, where $w^{j_{S}} \cdot j_{0} j_{D} \leqslant 1$. 
If ( $\mathrm{S}$ is $\left.A_{S}^{j_{S}}\right) A N D\left(\boldsymbol{O}\right.$ is $\left.A_{0}^{j_{0}}\right) A N D\left(D\right.$ is $\left.A_{D}^{j_{D}}\right)$,THEN (RPN is $100 \% \times$

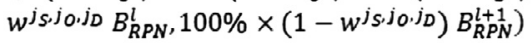

Fig. 23. A general fuzzy rule for fuzzy FMEA after refinement.

Rule 1:
If Occurrence is Very High, Severity is Very High, and Detect is Very
Low then the RPN is $\mathbf{1 0 0 \%}$ Extremely High
Rule 2:
If Occurrence is Very High, Severity is Very High, and Detect is Low
then the RPN is $\mathbf{8 0 \%}$ Extremely High, $\mathbf{2 0 \%}$ Very High

Fig. 24. An example of two fuzzy production rules after rule refinement.

Note that $b^{j_{S} \cdot j_{O} j_{D}}=w^{j_{S}} j_{0} j_{D} \times b_{R P N}^{l}+\left(1-w^{j_{S}} \cdot j_{O} j_{D}\right) \times b_{R P N}^{l+1}$. An example of the refined fuzzy rules is shown in Fig. 24. The fuzzy rules in Fig. 22 are further refined, as shown in Fig. 24. As can be seen from the example, inequality (4) is satisfied, whereby the consequent of rule \#2 is lower than that of rule \#1.

\section{Case study}

In this section, the application of the FIS-based RPN model to EBN processing is presented. In Section 4.1, the surface plots are firstly depicted and discussed. In Section 4.2, the fulfillment of the monotonicity property is analyzed with a monotonicity test. The details of the FMEA results are presented in Appendices, as these FMEA tables are large. In Appendix A, the FMEA tables for (i) swiftlets farming (P.1); (ii) harvesting (P.2); (iii) EBN cleaning (P.3); (iv) EBN drying and reshaping (P.4); and (v) storing and packaging (P.5), are presented. In Appendix B, the FMEA tables for tool and facility maintenance for (i) swiftlets farming (M.1); (ii) harvesting (M.2); (iii) EBN cleaning (M.3); and (iv) EBN drying and reshaping (M.4), are presented. The discussion of the risk ranking results is presented in Section 4.3 .

\subsection{Surface plots}

In Fig. 25, the surface plot for the FRPN score versus Occurrence and Detect with Severity $=10$ is presented. Fig. 26 shows the surface plot for the FRPN score versus Severity and Detect with Occurrence $=10$. Fig. 27 further depicts the surface plot for the FRPN scores versus Severity and Occurrence with Detect $=10$. As can be seen, these surface plots satisfy the monotonicity property.

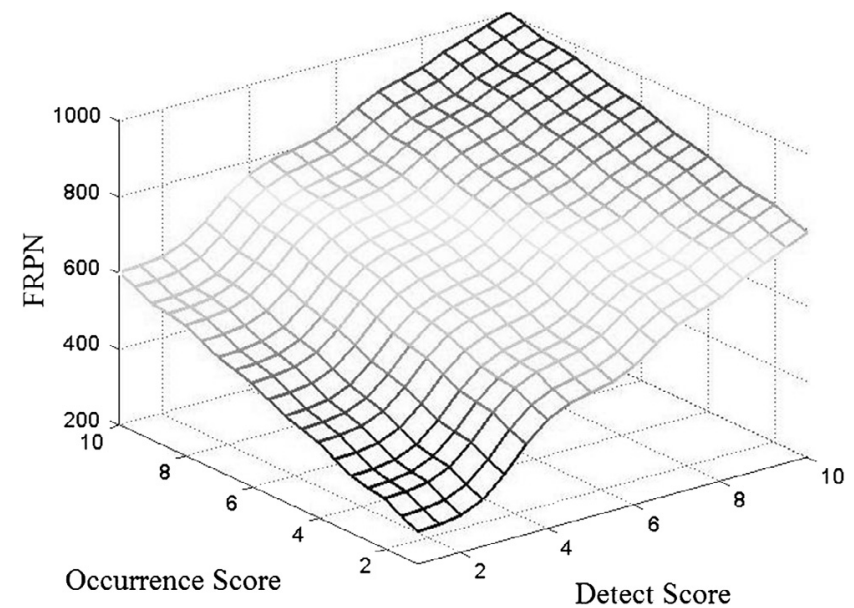

Fig. 25. Surface plot for FRPN versus Occurrence and Detect with Severity fixed at 10 (i.e., $S=10$ ).

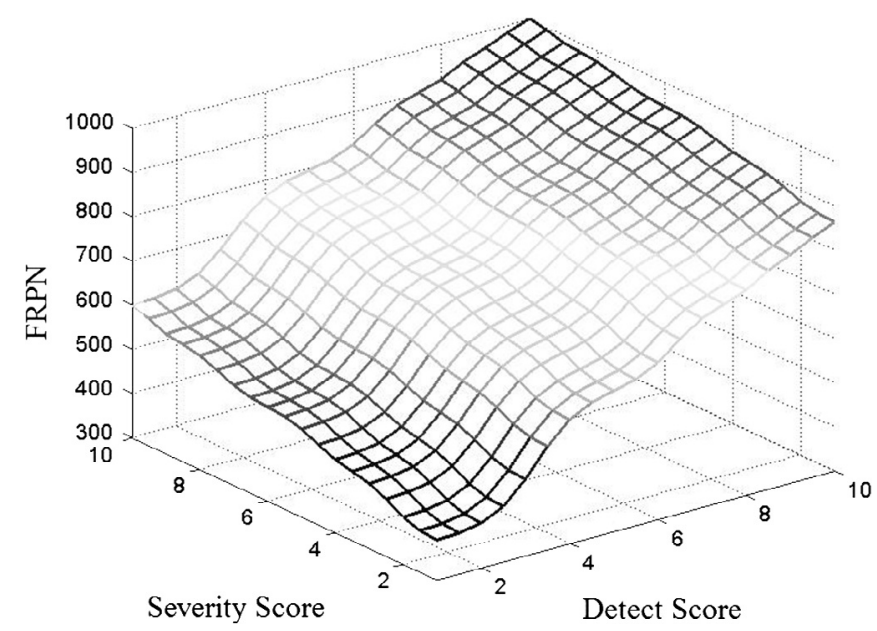

Fig. 26. Surface plot for FRPN versus Severity and Detect with Occurrence fixed at 10 (i.e., $O=10$ ).

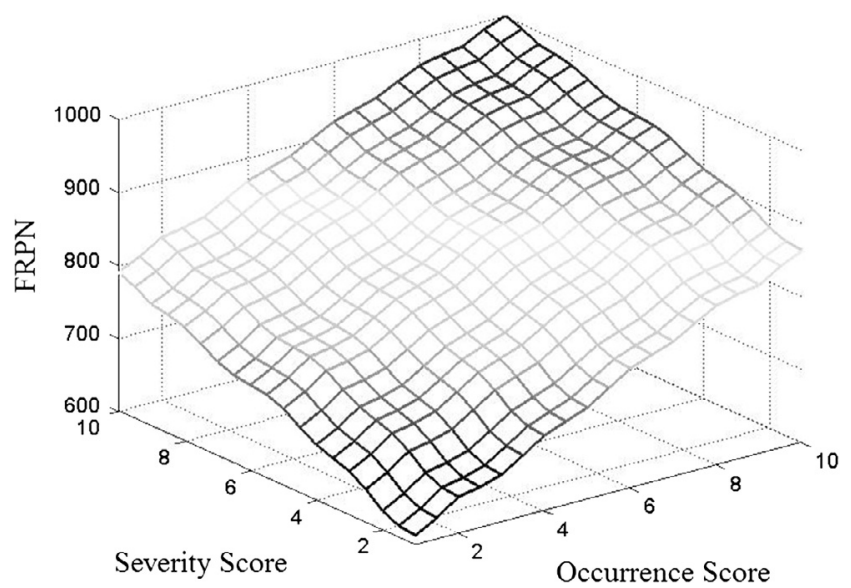

Fig. 27. Surface plot for FRPN versus Severity and Occurrence with Detect fixed at 10 (i.e., $D=10$ ).

In short, the FIS-based RPN model is able to produce valid and compare-able risk evaluation results.

\subsection{A monotonicity test}

In this section, a monotonicity test (Tay and Lim 2011b; Tay et al., 2012a,b) is used to evaluate whether the FIS-based RFN model satisfies the monotonicity property. The FIS-based RPN model is a three-input FIS model, i.e., $F R P N=f(\bar{x})$, where $\bar{x}=(S, O, D)$. We evaluate the monotonicity property between FRPN and $x_{i}$, where $x_{i} \in(S, O, D)$. Note that $\bar{s}$ (i.e., $x_{1}, x_{2} \in \bar{s}$ denotes a subset of $\bar{x}$ where $x_{i}$ is excluded from $\bar{s}$ (i.e., $\bar{s} \subset \bar{x} ; x_{i} \notin \bar{s}$ ).

Using the test procedure, each $S, O$ and $D$ is divided to $n$ divisions. In this study, $n=180$; thus the grid size, $g$, of each input (i.e., $S, O$ and $D$ ) is defined as $g=(10-1) / 180=0.05$. With Eq. (1), we denote $F R P N_{S, O, D}=f(S, O, D)$. To evaluate the monotonicity fulfillment of FRPN and $x_{i}$, each pair of $F R P N_{x_{i}=1+g \times m_{i}, \bar{s}}$ and $\operatorname{FRPN}_{x_{i}=1+g \times\left(m_{i}+1\right), \bar{s}}$, where $m_{i}=0,1,2, \ldots, n-1$, is compared. A function denoted by Monotone $\left(F R P N_{x_{i}=1+g \times m_{i}, \bar{s}}\right)$ is adopted, as in Eq. (5). To evaluate the monotonicity fulfillment degree, Eq. (6), is used. If Monotonicity test $\left(x_{i}\right)=(n+1)^{2} \times n$, the FIS-based RPN model is said to approximately satisfy monotonicity property. monotone $\left(F R P N_{x_{i}=1+g \times m_{i}, \bar{s}}\right)= \begin{cases}1 & F_{R P N} N_{x_{i}=1+g \times m_{i}, \bar{s}} \leq F R P N_{x_{i}=1+g \times\left(m_{i}+1\right), \bar{s}} \\ 0 & \text { else }\end{cases}$ 
Table 4

Results from the monotonicity test.

\begin{tabular}{ll}
\hline$x_{i}$ & Monotonicity test $\left(x_{i}\right)$ \\
\hline$S$ & $5,896,980$ \\
$O$ & $5,896,980$ \\
$D$ & $5,896,980$ \\
\hline
\end{tabular}

Monotonicity test $\left(x_{i}\right)=\sum_{m_{2}=0}^{m_{2}=n} \sum_{m_{1}=0}^{m_{1}=n} \sum_{m_{i}=0}^{m_{i}=n-1}\left(\right.$ monotone $\left.\left(\operatorname{FRPN}_{x_{i}=1+g \times m_{i}, x_{1}=1+g \times m_{1}, x_{2}=1+g \times m_{2}}\right)\right)$

Table 4 summaries the results of the monotonicity test for $x_{i}=S, O, D$. As $n=180, \quad$ Monotonicity test $\left(x_{i}\right)=(181)^{2} \times 180=$ $5,896,980$ leads to fulfillment of the monotonicity property. From Table $4, S, O$ and $D$ fulfill the monotonicity property. This implies that the FRPN scores produced by the FIS-based RPN model are valid and compare-able, and the FIS-based RPN model can be implemented in the real environment.

\subsection{Discussion}

Analysis of the FMEA results is as follows.

\subsubsection{Swiftlets farming}

The environmental control (i.e., P1.1) is one of the important aspects in the swiftlets farming process (i.e., P.1). From the results, farm temperature (i.e., P.1.1.1) and air quality of the farm (i.e., P.1.1.3) are associated with the highest RPN (i.e., both with RPN $=10$ ) and FRPN (i.e., FRPN $=165$ and FRPN $=286$, respectively) scores. With the traditional RPN model, the same RPN score is obtained with different combinations of $S, O, D$, i.e., 5, 1, 2 and $10,1,1$, respectively. Even though the RPN scores are the same, feedback and opinions from experts suggest the risks associated with both processes are different. Farm temperature is given an $S$ score of 5 , which implies a minor impact to the production yield. Air quality of the farm is given an $S$ score of 10 , which implies food safety and quality. Farm temperature and air quality of the farm are given $D$ scores of 1 and 2, respectively. These $D$ scores imply that even though detection for air quality of the farm is slightly better than that of farm temperature, both detection actions are still excellent and effective. Thus, more attention should be paid on the air quality of the farm.

With the FIS-based RPN model, air quality of the farm is associated with the highest FRPN score, and should be the first priority in swiftlets farming management. Feedback and opinions from domain experts suggest that this is a better choice. Nitride gas (i.e., $\mathrm{NO}_{3}$ ) evaporates from the wet decayed organic, and it is the main air pollutant in the farm. Nitride gas can be adsorbed by raw EBN, and this lead to the food safety issue. Thus, two actions are recommended, as follows: (1) make sure the floor is always dry, and the room temperature is controlled within $26-28^{\circ} \mathrm{C}$; (2) cleaning of the bird's excreta in the farm should be carried out frequently to avoid too much accumulated excreta in the farm. This issue can be resolved with a proper implementation of these two actions, and this leads to low $O$ and $D$ scores.

For pest and enemy control (i.e., P.1.2), Asian glossy starling (i.e., P.1.2.3) has been associated with the highest FRPN and RPN scores (i.e., FRPN $=479$ and RPN $=36$ ). This is followed by cockroach (i.e., P.1.2.7) with FRPN $=457$ and $R P N=14$, and home lizard (i.e., P.1.2.5) with FRPN $=368$ and $\mathrm{RPN}=12$. Both the traditional RPN model and the FIS-based RPN model suggest the same ranking outcome. Indeed, the invasion of these pests into the farm can hardly be avoided, and this is represented by high D scores (i.e., from 6 to 7). These pests destroy the swiftlets nest; hence the drop in the production of raw EBN.
For facility maintenance in swiftlets farming (i.e., M.1), the failure of power supply has been associated with the highest FRPN and RPN scores (i.e., FRPN $=766$ and RPN = 90). Again, both the traditional RPN model and the FIS-based RPN model suggest the same ranking outcome. The failure of power supply can threaten the safety and security of the farm, as most swiftlets farms rely only on the local wired electricity supply; hence, $S=9$. In addition, it is difficult to predict when a power failure would occur in advance; hence, $D=10$. However, this rarely happens; hence $O=1$.

\subsubsection{Harvesting}

The harvesting process (i.e., P.2) and its tool maintenance (i.e., M.2) are relatively simple, and have been associated with very low FRPN and RPN scores. Harvesting (i.e., P.2.1) has been associated with $S, O$, and $D$ of 3,1 , and 1, respectively, and with FRPN $=77$ and $\mathrm{RPN}=3$.

\subsubsection{EBN cleaning}

Most of the processes in EBN cleaning (i.e., P.3) have been associated with high $O$ scores. Cleaning with pincer (i.e., P.3.3) and cleaning with sprayer (i.e., P.3.4) have been assigned with an $O$ score of 10 , as these failures occur many times per hour. It is difficult to avoid EBN to be torn, and to ensure that it is totally cleaned. A torn EBN is considered as a low grade product. However, it is easy to visually inspect dirt and crack in EBN; hence $D=1$. P.3.3 and P.3.4 are repeated many times until EBN is clean; hence low $S$ scores for both P.3.3 and P.3.4.

In the EBN cleaning process, soaked in water (i.e., P.3.2) has the highest RPN score (i.e., RPN $=48$ ). Nevertheless, the risk evaluation with the FIS-based RPN model indicates that cleaning with sprayer (i.e., P3.3) have the highest FRPN score (i.e., FRPN $=465$ ) and soaked in water have the lowest FRPN score (FRPN = 339). Both soaked in water and cleaning with sprayer are assigned with $S, O$, $D$ scores of $4,6,2$ and $4,10,1$, respectively. The same $S$ score (i.e., $S=4$ ) is assigned to both the processes. Although the $D$ score for soaked in water (i.e., $D=2$ ) is slightly higher than that of cleaning with sprayer (i.e., $D=1$ ), cleaning with sprayer have a higher $O$ score (i.e., $O=10$ ) than soaked in water (i.e., $O=6$ ). These $D$ scores imply that even though detection for cleaning with sprayer is slightly better than that of soaked in water, both the detection actions are still excellent and effective. The $O$ scores of 6 and 10 refer to the frequency of Occurrence once in 1-30 days and many in $1 \mathrm{~h}$, respectively. A high $O$ score indicates that many products are affected by its potential failure mode. Thus, feedback and opinions from domain experts suggest that cleaning with sprayer should be the priority, instead of soaked in water.

For tool maintenance (i.e., M.3), they have been associated with low $D$ scores, because it is relatively easy to maintain the tools. Tools such as pincer (i.e., M3.1), workstation (i.e., M3.2), water container (i.e., M3.4) and sifter (i.e., M3.5) are associated with moderate FRPN scores (i.e., 327, 352, 391, and 263, respectively) because of the high $O$ scores (i.e., 6, 6, 10, and 6, respectively). However, these tools are associated with very low RPN scores (i.e., 24, 36, 10 , and 12 respectively). These tools should be frequently maintained to ensure the effectiveness of the EBN cleaning process (i.e., P.3). Domain experts suggest that these moderate FRPN scores are more appropriate to indicate the risk priority of these tools, instead of the low RPN scores.

\subsubsection{EBN drying and reshaping}

A dried EBN is fragile, and it cracks easily. A cracked EBN is considered as a low grade product. Thus, the processes in P.4 have been associated with rather high FRPN scores, i.e., above 500. Binding with thread (i.e., P.4.3) has been associated with the highest FRPN score, (i.e., FRPN = 591). This is followed by pressing (i.e., P4.4) and molding (i.e., P4.5), with FRPN $=574$. Indeed, these 
P.1 


\begin{tabular}{|c|c|c|c|c|c|c|c|c|c|c|c|c|}
\hline \multirow[t]{2}{*}{ Criterion } & \multirow{2}{*}{$\begin{array}{l}\text { Function and } \\
\text { description }\end{array}$} & \multirow[t]{2}{*}{ Root cause } & \multirow[t]{2}{*}{ Failure mode } & \multicolumn{2}{|l|}{ Failure effect } & \multirow{2}{*}{$\begin{array}{l}\text { Failure } \\
\text { detection }\end{array}$} & \multirow[t]{2}{*}{ SEV } & \multirow[t]{2}{*}{ OCC } & \multirow[t]{2}{*}{ DET } & \multirow[t]{2}{*}{ RPN } & \multirow[t]{2}{*}{ FRPN } & \multirow[t]{2}{*}{ Recommended actions } \\
\hline & & & & Local effect & $\begin{array}{l}\text { System } \\
\text { effect }\end{array}$ & & & & & & & \\
\hline $\begin{array}{l}\text { P.1.2.3 Asian } \\
\text { glossy starling } \\
\text { (Aplonis } \\
\text { Panayensis) } \\
\text { birds }\end{array}$ & $\begin{array}{l}\text { Asian glossy starling } \\
\text { control }\end{array}$ & $\begin{array}{l}\text { The birds may enter the farm } \\
\text { through the entrance. The birds } \\
\text { will compete with swiftlets for } \\
\text { the habitat }\end{array}$ & $\begin{array}{l}\text { Existence of } \\
\text { Asian glossy } \\
\text { starling in } \\
\text { the farm }\end{array}$ & $\begin{array}{l}\text { Destruction to the } \\
\text { swiftlets nest }\end{array}$ & $\begin{array}{l}\text { A drop in } \\
\text { the } \\
\text { production } \\
\text { of raw EBN }\end{array}$ & $\begin{array}{l}\text { Observation/ } \\
\text { Visual } \\
\text { Inspections }\end{array}$ & 6 & 1 & 6 & 36 & 479 & None \\
\hline P.1.2.4 Bat & $\begin{array}{l}\text { Bats control. Bats are a } \\
\text { natural enemy for } \\
\text { swiftlets. Bats eat raw } \\
\text { EBN, destruct the } \\
\text { habitat, and compete } \\
\text { with swiftlets for the } \\
\text { habitat }\end{array}$ & $\begin{array}{l}\text { Bats may enter the farm through } \\
\text { the roof, window and/or vents }\end{array}$ & $\begin{array}{l}\text { Existence of } \\
\text { bats in the } \\
\text { farm }\end{array}$ & $\begin{array}{l}\text { Destruction to the habitat } \\
\text { of swiftlets. Competitive } \\
\text { habitat for swiftlets }\end{array}$ & $\begin{array}{l}\text { A drop in } \\
\text { the } \\
\text { production } \\
\text { of raw EBN }\end{array}$ & $\begin{array}{l}\text { Observation/ } \\
\text { visual } \\
\text { inspections }\end{array}$ & 5 & 1 & 1 & 5 & 152 & $\begin{array}{l}\text { Keep the entrance to the } \\
\text { farm bright at night to } \\
\text { avoid bats }\end{array}$ \\
\hline \multirow[t]{4}{*}{$\begin{array}{l}\text { P.1.2.5 Home } \\
\text { lizard }\end{array}$} & $\begin{array}{l}\text { Home lizard control. } \\
\text { Home lizard eats raw } \\
\text { EBN and swiftlets eggs }\end{array}$ & $\begin{array}{l}\text { Home lizards may enter the farm } \\
\text { through roof, window and/or } \\
\text { vents }\end{array}$ & $\begin{array}{l}\text { Existence of } \\
\text { home lizards } \\
\text { in the farm }\end{array}$ & $\begin{array}{l}\text { Destruction to the } \\
\text { swiftlets nests }\end{array}$ & $\begin{array}{l}\text { A drop in } \\
\text { the } \\
\text { production } \\
\text { of raw EBN }\end{array}$ & $\begin{array}{l}\text { Observation/ } \\
\text { Visual } \\
\text { Inspections }\end{array}$ & 2 & 1 & 6 & 12 & 368 & 1. Set up traps \\
\hline & & & & $\begin{array}{l}\text { Destruction to the habitat } \\
\text { of swiftlets }\end{array}$ & & & & & & & & $\begin{array}{l}\text { 2. Cover the vents with } \\
\text { nets }\end{array}$ \\
\hline & & $\begin{array}{l}\text { Small hole, pit, gap or crack of } \\
\text { the farm may cause home lizards } \\
\text { to invade }\end{array}$ & & $\begin{array}{l}\text { Affecting the breeding of } \\
\text { the swiftlets }\end{array}$ & & & & & & & & $\begin{array}{l}\text { 3. Make sure there is no } \\
\text { hole, pit, gap, or crack }\end{array}$ \\
\hline & & & & & & & & & & & & $\begin{array}{l}\text { 4. Design a ditch or drain } \\
\text { system around the farm }\end{array}$ \\
\hline \multirow[t]{3}{*}{ P.1.2.6 Rat } & $\begin{array}{l}\text { Rats control. Rats eat } \\
\text { raw EBN, swiftlets eggs, } \\
\text { and their chicks }\end{array}$ & $\begin{array}{l}\text { Rats may enter the farm through } \\
\text { the roof, window and/or vents }\end{array}$ & $\begin{array}{l}\text { Existence of } \\
\text { rats in the } \\
\text { farm }\end{array}$ & $\begin{array}{l}\text { Destruction to the } \\
\text { swiftlets nests }\end{array}$ & $\begin{array}{l}\text { A drop in } \\
\text { the } \\
\text { production } \\
\text { of raw EBN }\end{array}$ & $\begin{array}{l}\text { Observation/ } \\
\text { visual } \\
\text { inspections }\end{array}$ & 3 & 1 & 2 & 6 & 92 & 1. Set up traps \\
\hline & & $\begin{array}{l}\text { Small hole, pit, gap, or crack of } \\
\text { the farm may cause rats to } \\
\text { invade }\end{array}$ & & $\begin{array}{l}\text { Destruction to the habitat } \\
\text { of swiftlets }\end{array}$ & & & & & & & & $\begin{array}{l}\text { 2. Make sure there is no } \\
\text { hole, pit, gap, or crack }\end{array}$ \\
\hline & & & & $\begin{array}{l}\text { Affecting the breeding of } \\
\text { the swiftlets }\end{array}$ & & & & & & & & $\begin{array}{l}\text { 3. Cut the trees around } \\
\text { the farm to avoid } \\
\text { invasion via tree }\end{array}$ \\
\hline \multirow[t]{2}{*}{ P.1.2.7 Cockroach } & Cockroaches control & $\begin{array}{l}\text { Small hole, pit, gap, or crack of } \\
\text { the farm may cause cockroaches } \\
\text { to invade }\end{array}$ & $\begin{array}{l}\text { Existence of } \\
\text { cockroaches } \\
\text { in the farm }\end{array}$ & $\begin{array}{l}\text { Destruction to the } \\
\text { swiftlets nest }\end{array}$ & $\begin{array}{l}\text { A drop in } \\
\text { the } \\
\text { production } \\
\text { of raw EBN }\end{array}$ & $\begin{array}{l}\text { Observation/ } \\
\text { visual } \\
\text { inspections }\end{array}$ & 2 & 1 & 7 & 14 & 457 & $\begin{array}{l}\text { 1. Cover the vents with } \\
\text { nest }\end{array}$ \\
\hline & & & & $\begin{array}{l}\text { Affecting the breeding of } \\
\text { the swiftlets }\end{array}$ & & & & & & & & $\begin{array}{l}\text { 2. Design a ditch or drain } \\
\text { system around the farm }\end{array}$ \\
\hline P.1.2.8 Ant & Ants control & $\begin{array}{l}\text { Small hole, pit, gap, or crack of } \\
\text { the farm may cause ants to } \\
\text { invade }\end{array}$ & $\begin{array}{l}\text { Existence of } \\
\text { ants in the } \\
\text { farm }\end{array}$ & $\begin{array}{l}\text { Affecting the breeding of } \\
\text { the swiftlets }\end{array}$ & $\begin{array}{l}\text { A drop in } \\
\text { the } \\
\text { production } \\
\text { of raw EBN }\end{array}$ & $\begin{array}{l}\text { Observation/ } \\
\text { Visual } \\
\text { Inspections }\end{array}$ & 3 & 1 & 1 & 3 & 77 & $\begin{array}{l}\text { Design a ditch or drain } \\
\text { system around the farm }\end{array}$ \\
\hline
\end{tabular}


P.2

\begin{tabular}{|c|c|c|c|c|c|c|c|c|c|c|c|c|}
\hline \multirow[t]{2}{*}{ Process } & \multirow[t]{2}{*}{ Function and description } & \multirow{2}{*}{$\begin{array}{l}\text { Root } \\
\text { cause }\end{array}$} & \multirow[t]{2}{*}{ Failure mode } & \multicolumn{2}{|l|}{ Failure effect } & \multirow[t]{2}{*}{ Failure detection } & \multirow[t]{2}{*}{ SEV } & \multirow[t]{2}{*}{ OCC } & \multirow[t]{2}{*}{ DET } & \multirow[t]{2}{*}{ RPN } & \multirow[t]{2}{*}{ FRPN } & \multirow{2}{*}{$\begin{array}{l}\text { Recommended } \\
\text { actions }\end{array}$} \\
\hline & & & & Local effect & System effect & & & & & & & \\
\hline P.2.1 Harvesting & $\begin{array}{l}\text { Shovel or harvest the raw EBN on the } \\
\text { crossbeam in the farm }\end{array}$ & $\begin{array}{l}\text { Human } \\
\text { errors }\end{array}$ & $\begin{array}{l}\text { Tearing of } \\
\text { raw EBN }\end{array}$ & $\begin{array}{l}\text { Destruction to the } \\
\text { raw EBNs }\end{array}$ & $\begin{array}{l}\text { Affect the cosmetic of } \\
\text { the product }\end{array}$ & $\begin{array}{l}\text { Observation/Visual } \\
\text { Inspections }\end{array}$ & 3 & 1 & 1 & 3 & 77 & None \\
\hline
\end{tabular}

P. 3

\begin{tabular}{|c|c|c|c|c|c|c|c|c|c|c|c|c|}
\hline \multirow[t]{2}{*}{ Process } & \multirow[t]{2}{*}{ Function and description } & \multirow[t]{2}{*}{ Root cause } & \multirow{2}{*}{$\begin{array}{l}\text { Failure } \\
\text { mode }\end{array}$} & \multicolumn{2}{|l|}{ Failure effect } & \multirow{2}{*}{$\begin{array}{l}\text { Failure } \\
\text { detection }\end{array}$} & \multirow[t]{2}{*}{ SEV } & \multirow[t]{2}{*}{ OCC } & \multirow[t]{2}{*}{ DET } & \multirow[t]{2}{*}{ RPN } & \multirow{2}{*}{$\begin{array}{l}\text { Fuzzy } \\
\text { RPN }\end{array}$} & \multirow{2}{*}{$\begin{array}{l}\text { Recommended } \\
\text { actions }\end{array}$} \\
\hline & & & & Local effect & System effect & & & & & & & \\
\hline $\begin{array}{l}\text { P.3.1 } \\
\text { Brushing } \\
\text { and } \\
\text { washing }\end{array}$ & Removing dirt & Human errors & $\begin{array}{l}\text { Tearing of } \\
\text { raw EBN }\end{array}$ & $\begin{array}{l}\text { Complicated cleaning } \\
\text { processes (P } 3.3 \text { and } \\
\text { P3.4) }\end{array}$ & $\begin{array}{l}\text { Degradation of EBN quality. Torn } \\
\text { EBN is classified as the 3rd class EBN }\end{array}$ & $\begin{array}{l}\text { Observation/ } \\
\text { visual } \\
\text { inspections }\end{array}$ & 4 & 9 & 1 & 36 & 422 & None \\
\hline $\begin{array}{l}\text { P.3.2 Soaked } \\
\text { in water }\end{array}$ & $\begin{array}{l}\text { Soften the raw EBN for the } \\
\text { contaminant cleaning } \\
\text { process }\end{array}$ & $\begin{array}{l}\text { Soaking in water for } \\
\text { too long }\end{array}$ & $\begin{array}{l}\text { Dissolution } \\
\text { of EBN }\end{array}$ & None & Degradation of EBN quality & $\begin{array}{l}\text { Observation/ } \\
\text { visual } \\
\text { inspections }\end{array}$ & 4 & 6 & 2 & 48 & 339 & None \\
\hline $\begin{array}{l}\text { P.3.3 } \\
\text { Cleaning } \\
\text { with } \\
\text { pincer }\end{array}$ & $\begin{array}{l}\text { Cleaning contaminant with } \\
\text { pincers }\end{array}$ & $\begin{array}{l}\text { Feather and dirt are } \\
\text { not properly } \\
\text { cleaned }\end{array}$ & Dirty EBN & $\begin{array}{l}\text { Complicated cleaning } \\
\text { processes (P } 3.3 \text { and } \\
\text { P3.4) }\end{array}$ & Degradation of EBN quality & $\begin{array}{l}\text { Observation/ } \\
\text { visual } \\
\text { inspections }\end{array}$ & 3 & 10 & 1 & 30 & 447 & None \\
\hline $\begin{array}{l}\text { P.3.4 } \\
\quad \text { Cleaning } \\
\text { with } \\
\text { sprayer }\end{array}$ & $\begin{array}{l}\text { Spaying water to clean the } \\
\text { dirt, particles, and small } \\
\text { feather }\end{array}$ & $\begin{array}{l}\text { Water pressure is } \\
\text { too high }\end{array}$ & $\begin{array}{l}\text { Tearing of } \\
\text { raw EBN }\end{array}$ & $\begin{array}{l}\text { Complicated cleaning } \\
\text { processes (P } 3.3 \text { and } \\
\text { P3.4) }\end{array}$ & $\begin{array}{l}\text { Complicated cleaning processes ( } P \\
3.3 \text { and P3.4) Degradation of EBN } \\
\text { quality }\end{array}$ & $\begin{array}{l}\text { Observation/ } \\
\text { Visual } \\
\text { Inspections }\end{array}$ & 4 & 10 & 1 & 40 & 465 & None \\
\hline
\end{tabular}


P. 4

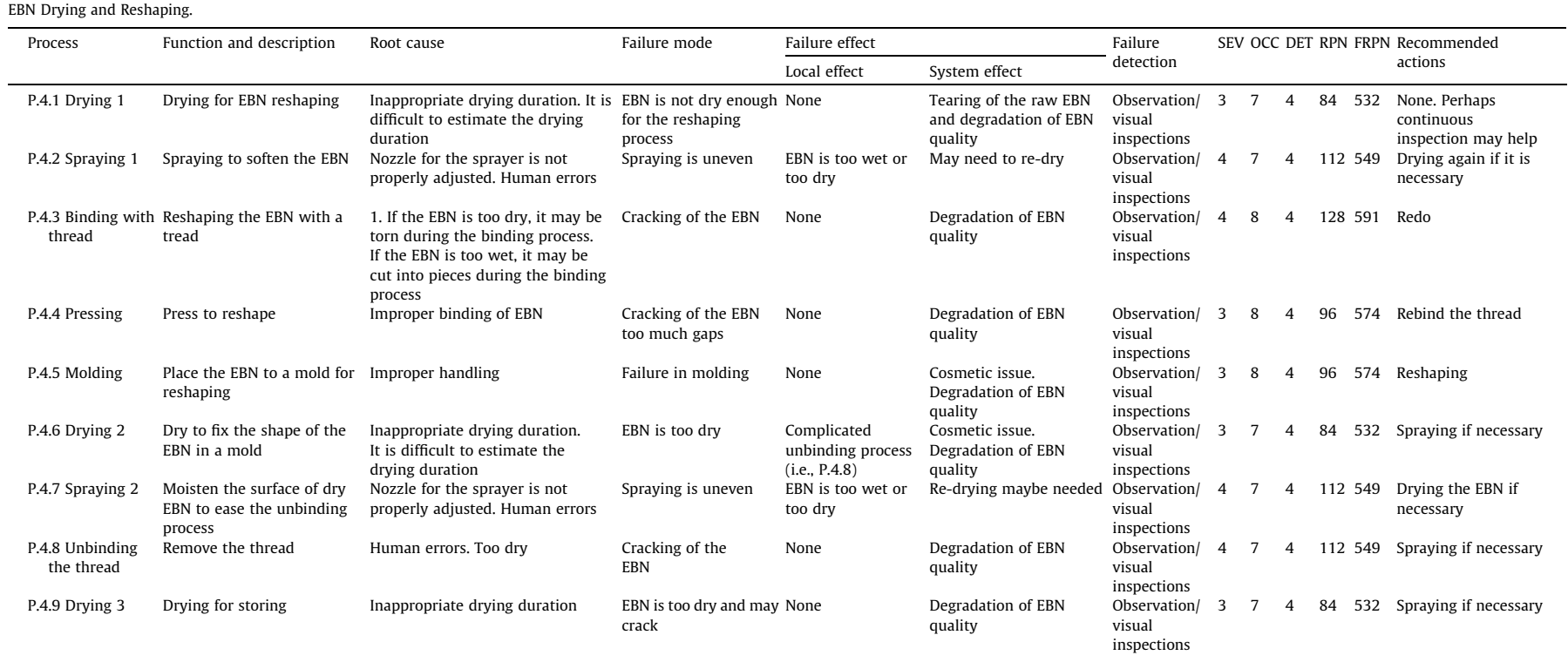


P.5

\begin{tabular}{|c|c|c|c|c|c|c|c|c|c|c|c|c|}
\hline \multirow[t]{2}{*}{ Process } & \multirow{2}{*}{$\begin{array}{l}\text { Function and } \\
\text { description }\end{array}$} & \multirow[t]{2}{*}{ Root cause } & \multirow[t]{2}{*}{ Failure mode } & \multicolumn{2}{|c|}{ Failure effect } & \multirow[t]{2}{*}{ Failure detection } & \multirow[t]{2}{*}{ SEV } & \multirow[t]{2}{*}{ occ } & \multirow[t]{2}{*}{ DET } & \multirow[t]{2}{*}{ RPN } & \multirow[t]{2}{*}{ FRPN } & \multirow{2}{*}{$\begin{array}{l}\text { Recommended } \\
\text { actions }\end{array}$} \\
\hline & & & & $\begin{array}{l}\text { Local } \\
\text { effect }\end{array}$ & System effect & & & & & & & \\
\hline $\begin{array}{l}\text { P. } 5.1 \text { Product Storing and } \\
\text { protection }\end{array}$ & $\begin{array}{l}\text { Temporary storage for } \\
\text { EBN }\end{array}$ & $\begin{array}{l}\text { Inappropriate } \\
\text { handling }\end{array}$ & $\begin{array}{l}\text { Cracking of the } \\
\text { EBN }\end{array}$ & None & $\begin{array}{l}\text { Degradation of EBN } \\
\text { quality }\end{array}$ & $\begin{array}{l}\text { Observation/visual } \\
\text { inspections }\end{array}$ & 3 & 1 & 1 & 3 & 77 & No solution \\
\hline P.5.2 Product Packing & Product packaging & $\begin{array}{l}\text { Inappropriate } \\
\text { handling }\end{array}$ & $\begin{array}{l}\text { Cracking of the } \\
\text { EBN }\end{array}$ & None & $\begin{array}{l}\text { Degradation of EBN } \\
\text { quality }\end{array}$ & $\begin{array}{l}\text { Observation/visual } \\
\text { inspections }\end{array}$ & 3 & 7 & 1 & 21 & 337 & $\begin{array}{l}\text { Use sponge or bubble } \\
\text { wrap }\end{array}$ \\
\hline
\end{tabular}

M.1

\begin{tabular}{|c|c|c|c|c|c|c|c|c|c|c|c|c|}
\hline \multirow[t]{2}{*}{ Facality } & \multirow{2}{*}{$\begin{array}{l}\text { Function and } \\
\text { description }\end{array}$} & \multirow[t]{2}{*}{ Root cause } & \multirow[t]{2}{*}{ Failure mode } & \multicolumn{2}{|l|}{$\underline{\text { Failure effect }}$} & \multirow{2}{*}{$\begin{array}{l}\text { Failure } \\
\text { detection }\end{array}$} & \multirow{2}{*}{\multicolumn{2}{|c|}{ SEV }} & \multirow[t]{2}{*}{ DET } & \multirow[t]{2}{*}{ r RPN } & \multirow{2}{*}{ FRPN } & \multirow{2}{*}{$\begin{array}{l}\text { Recommended } \\
\text { actions }\end{array}$} \\
\hline & & & & Local effect & System effect & & & & & & & \\
\hline \multicolumn{13}{|l|}{ Facilities maintenance } \\
\hline M.1.1 Alarm system & $\begin{array}{l}\text { Farm security and } \\
\text { avoidance of theft }\end{array}$ & $\begin{array}{l}\text { Faulty component in the } \\
\text { alarm system. Power supply } \\
\text { down }\end{array}$ & $\begin{array}{l}\text { Malfunction of } \\
\text { the alarm } \\
\text { system }\end{array}$ & None & Theft issue and loss in profit & $\begin{array}{l}\text { Preventive } \\
\text { maintenance }\end{array}$ & $e^{9}$ & 1 & 2 & 18 & 264 & $\begin{array}{l}\text { Preventive } \\
\text { maintenance }\end{array}$ \\
\hline M.1.2 Lighting system & $\begin{array}{l}\text { Prevent the } \\
\text { invasion of pests } \\
\text { at night }\end{array}$ & $\begin{array}{l}\text { Power supply down. } \\
\text { Malfunctioning of the lamp }\end{array}$ & $\begin{array}{l}\text { Malfunction of } \\
\text { the lighting } \\
\text { system }\end{array}$ & None & Invasion of pests & $\begin{array}{l}\text { Preventive } \\
\text { maintenance }\end{array}$ & $e^{5}$ & 1 & 4 & 20 & 377 & $\begin{array}{l}\text { Preventive } \\
\text { maintenance }\end{array}$ \\
\hline M.1.3 Power supply & $\begin{array}{l}\text { Provide electricity } \\
\text { to facilities }\end{array}$ & $\begin{array}{l}\text { Short circuit. Power station } \\
\text { or transformer station down }\end{array}$ & $\begin{array}{l}\text { Failure of power } \\
\text { supply }\end{array}$ & Malfunction of other facilities & $\begin{array}{l}\text { Affecting the safety of the farm. Invasion } \\
\text { of pests A drop in the swiftlets } \\
\text { population }\end{array}$ & $\begin{array}{l}\text { Preventive } \\
\text { maintenance }\end{array}$ & $e^{9}$ & 1 & 10 & 90 & 766 & $\begin{array}{l}\text { Preventive } \\
\text { maintenance }\end{array}$ \\
\hline \multirow[t]{2}{*}{ M.1.4 Sound system } & $\begin{array}{l}\text { Attract swiftlets } \\
\text { to nest in the } \\
\text { farm }\end{array}$ & $\begin{array}{l}\text { 1. Malfunction of the } \\
\text { amplifier or speaker }\end{array}$ & $\begin{array}{l}\text { Malfunction of } \\
\text { sound system }\end{array}$ & $\begin{array}{l}\text { Migration of the swiftlets and a } \\
\text { drop in the swiftlets } \\
\text { population }\end{array}$ & A drop in the production of raw EBN & $\begin{array}{l}\text { Preventive } \\
\text { maintenance }\end{array}$ & $e^{5}$ & 1 & 4 & 20 & 377 & $\begin{array}{l}\text { Preventive } \\
\text { maintenance }\end{array}$ \\
\hline & & $\begin{array}{l}\text { 2. Damage of the compact } \\
\text { disk }\end{array}$ & & & & & & & & & & \\
\hline M.1.5 Humidifier & $\begin{array}{l}\text { Maintain the } \\
\text { humidity of the } \\
\text { farm }\end{array}$ & Failure of water supply & $\begin{array}{l}\text { Malfunction of } \\
\text { the humidifier }\end{array}$ & $\begin{array}{l}\text { Migration of the swiftlets and a } \\
\text { drop in the swiftlets } \\
\text { population }\end{array}$ & A drop in of the production of raw EBN & $\begin{array}{l}\text { Preventive } \\
\text { maintenance }\end{array}$ & $e^{6}$ & 1 & 4 & 24 & 393 & $\begin{array}{l}\text { Preventive } \\
\text { maintenance }\end{array}$ \\
\hline
\end{tabular}


M.2

Harvesting.

\begin{tabular}{|c|c|c|c|c|c|c|c|c|c|c|c|c|}
\hline \multirow[t]{2}{*}{ Tools } & \multirow[t]{2}{*}{ Function and description } & \multirow[t]{2}{*}{ Root cause } & \multirow[t]{2}{*}{ Failure mode } & \multicolumn{2}{|l|}{ Failure effect } & \multirow{2}{*}{$\begin{array}{l}\text { Failure } \\
\text { detection }\end{array}$} & \multirow[t]{2}{*}{ SEV } & \multirow[t]{2}{*}{ oCC } & \multirow[t]{2}{*}{ DET } & \multirow[t]{2}{*}{ RPN } & \multirow[t]{2}{*}{ FRPN } & \multirow[t]{2}{*}{ Recommended actions } \\
\hline & & & & Local effect & $\begin{array}{l}\text { System } \\
\text { effect }\end{array}$ & & & & & & & \\
\hline \multicolumn{13}{|l|}{ Tool maintenance } \\
\hline $\begin{array}{l}\text { M.2.1 Taping } \\
\text { knife }\end{array}$ & $\begin{array}{l}\text { Shovel or harvest the raw EBN } \\
\text { on the crossbeams }\end{array}$ & $\begin{array}{l}\text { Inappropriate } \\
\text { handling }\end{array}$ & $\begin{array}{l}\text { Abrasion of the taping } \\
\text { knife }\end{array}$ & $\begin{array}{l}\text { Affecting the efficiency of the } \\
\text { harvesting process }\end{array}$ & None & $\begin{array}{l}\text { Visual } \\
\text { inspections }\end{array}$ & 2 & 1 & 1 & 2 & 23 & $\begin{array}{l}\text { Use the grindstone to keep the } \\
\text { taping knife sharp }\end{array}$ \\
\hline $\begin{array}{l}\text { M.2.1 Swiftlets } \\
\text { corner mirror }\end{array}$ & $\begin{array}{l}\text { Inspection of bird nests before } \\
\text { harvesting }\end{array}$ & $\begin{array}{l}\text { Inappropriate } \\
\text { handling }\end{array}$ & $\begin{array}{l}\text { Cracking of the } \\
\text { swiftlets corner mirror }\end{array}$ & $\begin{array}{l}\text { Affecting the efficiency of the } \\
\text { harvesting process }\end{array}$ & None & $\begin{array}{l}\text { Visual } \\
\text { inspections }\end{array}$ & 1 & 1 & 1 & 1 & 1 & None \\
\hline
\end{tabular}

M.3
EBN Cleaning.

\begin{tabular}{|c|c|c|c|c|c|c|c|c|c|c|c|c|}
\hline \multirow[t]{2}{*}{ Tools } & \multirow[t]{2}{*}{ Function and description } & \multirow[t]{2}{*}{ Root cause } & \multirow[t]{2}{*}{ Failure mode } & \multicolumn{2}{|l|}{ Failure effect } & \multirow{2}{*}{$\begin{array}{l}\text { Failure } \\
\text { detection }\end{array}$} & \multirow{2}{*}{\multicolumn{2}{|c|}{ SEV OCC }} & DE & \multirow[t]{2}{*}{ ET RPN } & \multirow[t]{2}{*}{ N FRPN } & \multirow[t]{2}{*}{ Recommended actions } \\
\hline & & & & Local effect & System effect & & & & & & & \\
\hline \multicolumn{13}{|c|}{ Tool maintenance } \\
\hline $\begin{array}{ll}\text { M.3.1 Pincers } & 1 \\
& 1\end{array}$ & $\begin{array}{l}\text { To clean the raw EBN and } \\
\text { remove contaminant }\end{array}$ & Inappropriate handling & Pincers is blunt & $\begin{array}{l}\text { Increasing the risk of raw } \\
\text { EBN to be torn }\end{array}$ & $\begin{array}{l}\text { Degradation of } \\
\text { EBN quality }\end{array}$ & $\begin{array}{l}\text { Preventive } \\
\text { maintenance }\end{array}$ & 4 & 6 & 1 & 24 & 327 & $\begin{array}{l}\text { Use the grindstone to } \\
\text { keep the pincers sharp }\end{array}$ \\
\hline $\begin{array}{l}\text { M.3.2 } \\
\text { Workstation } \\
\text { platform }\end{array}$ & $\begin{array}{l}\text { To support the cleaning } \\
\text { process }\end{array}$ & $\begin{array}{l}\text { Inappropriate handling. The workstation } \\
\text { platform is not properly maintained }\end{array}$ & $\begin{array}{l}\text { The workstation } \\
\text { platform is dirty }\end{array}$ & $\begin{array}{l}\text { Affecting the efficiency of } \\
\text { the cleaning processes }\end{array}$ & $\begin{array}{l}\text { Degradation of } \\
\text { EBN quality }\end{array}$ & $\begin{array}{l}\text { Preventive } \\
\text { maintenance }\end{array}$ & 2 & 6 & 3 & 36 & 352 & Preventive maintenance \\
\hline M.3.3 Sprayer & $\begin{array}{l}\text { A tool to clean the raw } \\
\text { EBN contaminant }\end{array}$ & Malfunctioning of the air pump & $\begin{array}{l}\text { Unstable water } \\
\text { pressure }\end{array}$ & $\begin{array}{l}\text { Affecting the efficiency of } \\
\text { the cleaning processes }\end{array}$ & $\begin{array}{l}\text { Degradation of } \\
\text { EBN quality }\end{array}$ & $\begin{array}{l}\text { Preventive } \\
\text { maintenance }\end{array}$ & 2 & 2 & 3 & 12 & 187 & Preventive maintenance \\
\hline $\begin{array}{l}\text { M.3.4 Water } \\
\text { container }\end{array}$ & A container to keep water & $\begin{array}{l}\text { Inappropriate handling. Water needs to be } \\
\text { changed from time to time }\end{array}$ & $\begin{array}{l}\text { Too much } \\
\text { contaminant in the } \\
\text { water }\end{array}$ & $\begin{array}{l}\text { Affecting the efficiency of } \\
\text { the cleaning processes }\end{array}$ & None & $\begin{array}{l}\text { Preventive } \\
\text { maintenance }\end{array}$ & 1 & 10 & 1 & 10 & 391 & $\begin{array}{l}\text { Change the water in the } \\
\text { container frequently }\end{array}$ \\
\hline M.3.5 Sifter & $\begin{array}{l}\text { To hold the wet raw EBN } \\
\text { while cleaning }\end{array}$ & Inappropriate handling & Dirty sifter & None & $\begin{array}{l}\text { Complicated } \\
\text { cleaning process }\end{array}$ & $\begin{array}{l}\text { Preventive } \\
\text { maintenance }\end{array}$ & 2 & 6 & 1 & 12 & 263 & $\begin{array}{l}\text { Clean the sifter } \\
\text { frequently }\end{array}$ \\
\hline M.3.6 Magnifier ${ }_{i}$ & $\begin{array}{l}\text { To ease the visual } \\
\text { inspection of EBN }\end{array}$ & Cumulative dust & $\begin{array}{l}\text { The magnifier is } \\
\text { dirty }\end{array}$ & $\begin{array}{l}\text { Affecting the efficiency of } \\
\text { the cleaning processes }\end{array}$ & None & $\begin{array}{l}\text { Preventive } \\
\text { maintenance }\end{array}$ & 1 & 2 & 1 & 2 & 61 & $\begin{array}{l}\text { Clean the magnifier } \\
\text { frequently }\end{array}$ \\
\hline
\end{tabular}


processes are the most complicated ones for P.4, and they usually require skilled workers.

With the traditional RPN model, the RPN scores are relatively low, i.e., from 84 to 128 . Feedbacks and opinions from expert domains suggest that the ranking outcomes from the traditional RPN model are doubtful, as the processes in P.4 are risky and complicated. Besides, skilled workers are required in P.4. Both the traditional RPN and the FIS-based RPN models suggest that binding with thread (i.e., P.4.3) should be the priority.

The oven (i.e., M.4.1) is the main facility in EBN drying and reshaping. It consists of a casing (M.4.1.1), bulbs (M.4.1.2), a fan (M.4.1.3), and nets (M.4.1.4). The task of maintaining the oven is simple, and has been associated with low FRPN and very low RPN scores. Effective detection strategies are also available; hence the $D$ scores are 1, 1, 3, and 3 for M.4.1.1, M.4.1.2, M.4.1.3, and M.4.1.4, respectively. Frequent cleaning of the oven parts is the most effective way to maintain the cleanliness of the oven.

\subsubsection{Storing and packaging}

Product storing and packing (P.5) is another simple process. As such, its sub-processes have been associated with low FRPN scores, i.e., FRPN of 337 and 77 for product packing (P.5.2) and product storing and protection (P.5.1), respectively. With the traditional RPN model, the RPN scores are low too, i.e., 21 and 3, respectively. Product packing has higher FRPN and RPN scores than those of product storing and protection, as the EBN has a higher risk to become crack during packing.

\section{Summary}

In this paper, the use of the fuzzy FMEA methodology to analyze the EBN production processes in Sarawak, Malaysia, has been studied. The potential failure modes have been identified and analyzed based on their effects, root causes, and detection methods. The FMEA tables have been formulated, and the $S, O$, and $D$ scores have been obtained. The RPN and FRPN scores have also been computed, with the results analyzed and discussed. The contributions of this paper are two folds. On one hand, this study addresses the issues of control and management of EBN processing with a formal and effective quality and risk assessment tool. On the other hand, it contributes towards a new application of the fuzzy FMEA methodology to the agriculture and food production domain.

For further studies, investigations on the use of fuzzy FMEA in other valuable food processing and agricultural products can be conducted. Examples include risk assessment in palm oil plantation and Tor Duoronensis fish farming. These are some of the important industries that require proper quality and risk assessment tools for their production in Sarawak.

\section{Acknowledgements}

The authors gratefully acknowledge the Exploratory Research Grant Scheme (ERGS/1/11/TK/UNIMAS/03/05) and Fundamental Research Grant Scheme (Nos. 6711229, 6711195, FRGS/1/2013/ ICT02/UNIMAS/02/1) for supporting this research work and UNIMAS for the facilities.

\section{Appendix A. EBN production process}

P.1.

P.2.

P.3.

P.4.

P.5. 


\section{Appendix B. Tool and facility maintenance}

M.1.

M.2.

M.3.

M.4.

\section{References}

Arvanitoyannis, I.S., Varzakas, T.H., 2008. Application of ISO 22000 and Failure Mode and Effect Analysis (FMEA) for industrial processing of salmon: a case study. Critical Reviews in Food Science and Nutrition 48, 411-429.

Bowles, J.B., Peláez, C.E., 1995. Fuzzy logic prioritization of failures in a system failure mode, effects and criticality analysis. Reliability Engineering and System Safety 50, 203-213.

Guimares, A.C.F., Lapa, C.M.F., 2004. Fuzzy FMEA applied to PWR chemical and volume control system. Progress in Nuclear Energy 44, 191-213.

Guo, C.T., Takahashi, T., Bukawa, W., Takahashi, N., Yagi, H., Kato, K., Jwa Hidari, K I.P., Miyamoto, D., Suzuki, T., Suzuki, Y., 2006. Edible bird's nest extract inhibits influenza virus infection. Antiviral Research 70, 140-146.

Hahn, F., 2011. Fuzzy controller decreases tomato cracking in greenhouses. Computers and Electronics in Agriculture 77, 21-27.

Hobbs, J.J., 2004. Problems in the harvest of edible birds' nests in Sarawak and Sabah, Malaysian Borneo. Biodiversity and Conservation 13, 2209-2226.

Jang, J.S.R., Sun, C.T., Mizutani, E., 1997. Neuro-fuzzy and soft computing: a computational approach to learning and machine intelligence. Prentice-Hall, US.

Jordan, D., 2009. Globalization and bird's nest soup. International Development Planning Review 26, 97-110.

Kolhe, S., Kamal, R., Saini, H.S., Gupta, G.K., 2011. A web-based intelligent diseasediagnosis system using a new fuzzy-logic based approach for drawing the inferences in crops. Computers and Electronics in Agriculture 76, 16-27.

Kouikoglou, V.S., Phillis, Y.A., 2009. On the monotonicity of hierarchical sumproduct fuzzy systems. Fuzzy Sets and Systems 160, 3530-3538.

Lim, C.K., Earl of Cranbrook, 2002. Swiflets of Borneo: Builder of Edible Nest. Natura History Publications, Borneo.

Lin, C.T., Lee, C.S.G., 1996. Neural fuzzy systems: a neuro fuzzy synergism to intelligent systems. Prentice Hall, Upper Saddle River, NJ.

Lin, J.R., Zhou, H., Lai, X.P., Hou, Y., Xian, X.M., Chen, J.N., Wang, P.X., Zhou, L., Dong, Y., 2009. Genetic identification of edible birds' nest based on mitochondrial DNA sequences. Food Research International 42, 1053-1061.

Liu, J., Martínez, L., Wang, H., Rodríguez, R.M., Novozhilov, V., 2010. Computing with words in risk assessment. International Journal of Computational Intelligence Systems 3, 396-419.

Marcone, M.F., 2005. Characterization of the edible bird's nest the "Caviar of the East". Food Research International 38, 1125-1134.

Marcone, M.F., 2011. Origins and compositional analysis of novel foods: kopi luwak coffee and bird's nest soup. In: Murray, M-Y, Michael, B., Colin W., Antonio, M. Fengwu, B., Comprehensive Biotechnology, Pergamon Press, Europe, pp. 683702.
Matsukwa, N., Matsumoyo, M., Bukawa, W., Chihi, H., Nakayama, K., Hara, H., Tsukahara, T., 2011. Improvement of bone strength and dermal thickness due to dietary edible bird's nest extract in ovariectomized rats. Bioscience, Biotechnology, and Biochemistry 75, 590-592.

Ozilgen, S., Bucak, S., Ozilgen, M., in press. Improvement of the safety of the red pepper spice with FMEA and post processing EWMA quality control charts. Journal of Food Science and Technology doi: http://dx.doi.org/10.1007/s13197011-0371-7.

Papadopoulos, A., Kalivas, D., Hatzichristos, T., 2011. Decision support system for nitrogen fertilization using fuzzy theory. Computers and Electronics in Agriculture 78, 130-139.

Piegat, A., 2001. Fuzzy Modeling and Control. Springer-Verlag, New York, USA

Scipioni, A., Saccarola, G., Arena, F., Alberto, S., 2005. Strategies to assure the absence of GMO in food products application process in a confectionery firm. Food Control 16, 569-578.

Scipioni, A., Saccarola, G., Centazzo, A., Arena, F., 2002. FMEA methodology design, implementation and integration with HACCP system in a food company. Food Control 13, 495-501.

Stamatis, D.H., 2003. Failure Mode and Effect Analysis (FMEA) from theory to execution. American Society for Quality Press, USA.

Tay, K.M., Lim, C.P., 2006. Fuzzy FMEA with guided rules reduction system for prioritization of failures. International Journal of Quality and Reliability Management 23, 1047-1066.

Tay, K.M., Lim, C.P., 2008a. On the use of fuzzy inference techniques in assessment models: Part I - Theoretical properties. Fuzzy Optimization and Decision Making 7, 269-281.

Tay, K.M., Lim, C.P., 2008b. On the use of fuzzy inference techniques in assessment models: Part II: Industrial applications. Fuzzy Optimization and Decision Making 7, 283-302.

Tay, K.M., Lim, C.P., 2011a. On monotonic sufficient conditions of fuzzy inference systems and their applications. International journal of uncertainty, fuzziness and knowledge-based systems 19, 731-757.

Tay, K.M., Lim, C.P., 2011b. Optimization of Gaussian fuzzy membership function and evaluation of the monotonicity property of fuzzy inference systems. IEEE International Conference on Fuzzy Systems 2011, 1219-1224.

Tay, K.M., Lim, C.P., Jee, T.L., 2012a. Building monotonicity-preserving fuzzy inference models with optimization-based similarity reasoning and a monotonicity index. IEEE International Conference on Fuzzy Systems 2012, 1-8.

Tay, K.M., Lim, C.P., The, C.Y., Lau, S.H., 2012b. A monotonicity index for the monotone fuzzy modeling problem. IEEE International Conference on Fuzzy Systems 2012, 1-8.

Won, J.M., Park, S.Y., Lee, J.S., 2002. Parameter conditions for monotonic TakagiSugeno-Kang fuzzy system. Fuzzy Sets and Systems 132, 135-146.

Wu, Y.J., Chen, Y., Wang, B., Bai, L.Q., Han, W.R., Ge, Y.Q., Yuan, F., 2010. Application of SYBRgreen PCR and 2DGE methods to authenticate edible bird's nest food. Food Research International 43, 2020-2026.

Yagi, H., Yasukawa, N., Yu, S.Y., Guo, C.T., Takahashi, N., Takahashi, T., Bukawa, W., Suzuki, T., Khoo, K.H., Suzuki, Y., Kato, K., 2008. The expression of sialylated high-antennary N-glycans in edible bird's nest. Carbohydrate Research 343 , 1373-1377.

Yang, Z., Bonsall, S., Wang, J., 2008. Fuzzy rule-based Bayesian reasoning approach for prioritization of failures in FMEA. IEEE Transactions on Reliability 57, $517-$ 528. 